\title{
Fission-track analysis of detrital zircon
}

\author{
M. Bernet ${ }^{1}$ and J. I. Garver ${ }^{2}$ \\ ${ }^{1}$ Department of Geosciences \\ State University of New York \\ New Paltz, NY, 12561, USA \\ email:matthias.bernet@aya.yale.edu \\ ${ }^{2}$ Geology Department \\ Olin Building, Union College \\ Schenectady, NY, 12308-3107, USA \\ email: garverj@union.edu
}

\section{INTRODUCTION}

Zircon has become one of the most important minerals for studying sediment provenance and the exhumation history of orogenic belts. The reason for this utility is that zircon is common in many igneous, metamorphic, and sedimentary rocks, it is resistant to weathering and abrasion, and it can be dated with various isotopic methods having reasonable high concentrations of uranium and thorium (Fig. 1). Techniques used to date detrital zircon include $\mathrm{U} / \mathrm{Pb}$ and $(\mathrm{U}-\mathrm{Th}) / \mathrm{He}$ dating, but in this chapter we focus exclusively on fission-track (FT) analysis.

FT analysis allows age determination of single zircon grains that may have cooling ages between several hundred thousand to a billion years or more. The datable range depends on individual uranium content and cooling history of a zircon grain. Fission tracks in zircon have an effective annealing temperature of $\sim 240^{\circ} \mathrm{C}+/-30^{\circ} \mathrm{C}$ in natural systems (Hurford 1986; Brandon et al. 1998; Bernet et al. 2002). Therefore most detrital zircon are fairly resistant to thermal annealing in typical sedimentary basins after deposition, while the other low-temperature thermochronometers anneal at lower temperatures common in sedimentary basins (i.e. Helium dating and apatite FT) and therefore more readily have compromised provenance information (Fig. 2). Consequently, the strength of detrital zircon fission-track (DZFT) analysis lies in the fact that this method provides robust cooling ages of source terrains. The ability of zircon to retain information about the most recent thermal history of a source area is invaluable in elucidating the processes and system response in a range of geodynamic settings, especially the evolution of orogenic belts. This characteristic makes DZFT dating 
superior to $\mathrm{U} / \mathrm{Pb}$ dating when the objective is to link sedimentation to the uplift and exhumation history of the source terrain. $\mathrm{U} / \mathrm{Pb}$ dating of single crystals provides crystallization ages (or zircon growth during metamorphism), which typically pre-date the latest orogenic cycle. This long-term memory is partly due to the fact that zircon is so robust that recycling is common and it is typical for zircons to be polycyclic, even in crustal melts. As such, a U/Pb age on a detrital zircon may have little bearing on the nature of the immediate source rock, but may be ideal for understanding the long-term record of crustal formation. In addition, $\mathrm{U} / \mathrm{Pb}$ ages of detrital zircon rarely allow the determination of exhumation rates and because of the possibility of multiple recycling of zircon grains their $\mathrm{U} / \mathrm{Pb}$ ages can only vaguely be assigned to non-distinct source regions. Therefore, FT ages tend to be directly related to actively evolving source terrains.

Consequently, as we explain below, DZFT analysis is a method ideally suited for: a) tracing the provenance of clastic sediments; b) determining stratigraphic ages in volcanically active areas; c) studying the long-term exhumation history of convergent mountain belts with little active volcanism, and d) dating low-temperature thermal events. Some interesting recent work has been aimed at combining DZFT with U/Pb or (U-Th)/He dating on the same grains or samples (see below, i.e. Reiners et al. in review).

In this chapter we explain basic aspects of DZFT analysis, and provide some practical considerations on sampling techniques in the field and laboratory analysis. We then show how results can be presented and discuss the interpretation of fission-track grain-age (FTGA) distributions in several different applications. Finally, we give an overview of the current developments in DZFT analysis and end by outlining some outstanding issues that need further attention.

\section{FISSION-TRACK DATING OF DETRITAL ZIRCON}

This section is meant to be an introduction to practical and technical aspects of FT analysis on detrital zircon. The basics of ZFT analysis are reviewed elsewhere (i.e. see Tagami et al. 2005), so here we highlight the principal methodological aspects that are unique to analysis of detrital zircon.

\section{Field collection}


Fission-track analysis can be preformed on detrital zircon from any clastic sedimentary environment, but most studies have focused on ancient sandstones and a few have investigated zircon from modern environments such as fluvial and beach facies. Sampling techniques are different for both kinds of samples (rock or sediment) and sampling strategies depend on the intended study. For exhumation and provenance studies one should carefully consider where in the field samples are collected. For example, regional studies require samples collected from river deltas of large-scale drainages, from marine turbidite sequences in the outcrop, or from drill-cores, if available. In any case, the most common mistake is that too little sample is collected (see suggestions below) and too few zircons are separated for proper analysis.

Zircon and source rocks. A crucial first step is to understand the nature of the source rock and whether that rock will yield zircon in an appreciable quantity. Geologic maps usually provide reasonable information about the potential zircon yield that can be expected in any given drainage area, but obviously the source for ancient sequences can be more difficult to infer. Zircon is a common accessory mineral in many acidic and sodium rich igneous rocks such as granite, granodiorite, tonalite or rhyolite and their metamorphic equivalents (see Table 1; Poldervaat 1955, 1956; Deer et al. 1992). As such, zircon occurs in siliciclastic deposits derived from such source rocks. In many river drainages the variety of gravels in the riverbed will provide a quick overview of lithology in the source area, but they are likely to be biased towards more resistant lithologies.

Owing to its stability (hardness of 7.5; lacks distinct cleavage) zircon survives significant weathering and transport while other detrital components are selectively removed. This trend is reflected in the zircon-tourmaline-rutile (ZTR) index for heavy minerals in clastic sedimentary rocks. This index is used to semi-quantitatively evaluate sediment maturity and source rock weathering, and increases when these three very stable minerals are relatively enriched in the heavy mineral fraction of clastic sediment by either transport or dissolution (e.g. Morton 1984; Mange and Maurer 1992). For example quartz arenite and quartzite have a particularly high ZTR index and commonly at least an intermediate zircon yield. Lithologies with unusually low zircon yield include carbonates, mafic rocks, and ultramafic rocks (Table 1). 
Recent sediment. Collecting detrital zircon samples from Recent sediment and loosely consolidated sedimentary rock is relatively simple. Zircon, commonly of fine sand size in detrital samples, has a density of $\sim 4.55-4.65 \mathrm{~g} / \mathrm{cm}^{3}$ (Deer et al. 1992), so its settling velocity is similar to quartz grains of medium sand size. For this reason zircon is typically deposited with somewhat coarser grained material, and samples should be preferably collected from sand bars and beaches with coarse- to medium-sand grain sizes. Simple gravity separation in the field (i.e. gold panning), can easily concentrate zircon so that a final density separation in the lab involves only a small quantity of material (200-300 g instead of 2-4 kg). Therefore, loose sediment can be directly processed in gold pans, and panning removes the lighter material (quartz, feldspar, micas etc.) and enriches the heavy minerals such as zircon, garnet, magnetite and even gold. In general, it is sufficient to pan between 12-14 pans of material, but the final outcome depends on zircon yield, panning efficiency, etc.

It is also possible to collect samples from gravel bars. In this case, gravel and all finer grained material can be run through a coarse sieve. The finer fraction (coarse to fine sand and smaller sizes) should be retained and processed further in the gold pan, while all coarse material ( $>2 \mathrm{~mm}$ ) can be discarded. It is worthwhile to look for heavy mineral placer deposits, which can be easily recognized by black and reddish colors from magnetite and garnet. If placer deposits are available it is not even necessary to use gold pans, because the top layers of the placer deposits can be scraped from the surface. If only loose sediment is collected for processing in the lab, without panning in the field, one should collect at least 4-7 kg of sample material. However, even this size of sample may not have sufficient zircon if the source lithology is not zircon bearing.

Ancient sandstone. Collecting samples from sandstone outcrops for DZFT analysis is routine, but there are some important considerations to bear in mind. All sample sizes suggested here are based on our experience in a number of different geodynamic settings of different composition and age. We find that the best samples are medium-grained arkosic sandstones and $2 \mathrm{~kg}$ of sample is generally sufficient, but many sandstone compositions are appropriate for collection and zircon extraction. Samples of lithic sandstone samples should be 4-7 kg. The presence of visible quartz is generally a good indicator, because quartz-rich lithologies require smaller samples (Table 2). The target grain size should be medium- to coarse-grained sandstone: fine-grained sandstone 
should be avoided, but collected only as a last resort (see below: fine-grained sandstones can yield c. $50 \mu \mathrm{m}$ zircons, which are possible to analyze). For graded beds (i.e. sandy turbidites), this observation requires that in some cases only the base of a bed is sampled.

The yield of zircon from most sandstone is usually satisfactory because many common lithologies produce appreciable yield and post-depositional modification is not significant. However, detrital apatite is much less predictable because it is more variable in source rock, and it can be severely affected by post-depositional dissolution. If the aim is to analyze detrital apatite as well, then it is important to avoid altered sandstones, especially those with excessive iron oxide and evidence of interstratal dissolution. These strata may have very poor yields of apatite, and there may be significant secondary minerals such as pyrite, siderite, or barite.

\section{Analytical considerations in the lab}

Mineral separation. After the samples have been collected in the field it is necessary to extract zircons in the laboratory with standard heavy liquid and magnetic separation techniques (Table 3). When large amounts of kyanite, barite, or pyrite are present in the zircon fraction, it may be necessary to further concentrate the zircon by hand picking, or it is possible to remove pyrite with $5 \mathrm{~N} \mathrm{HNO}_{3}$ over 24 hours, which leaves zircon unaffected.

Mounting. Separated zircons are mounted in PFA or FEP Teflon ${ }^{1}$, as is routine in ZFT analysis, but there are a few aspects unique to DZFT analysis. Depending on available sample material we like to include 200 to 1000 zircons in a mount $\left(\sim 2 \times 2 \mathrm{~cm}^{2}\right)$ to easily ensure that 50-100 randomly selected grains can be dated per sample. The number of grains on the mount is important because a large fraction will be uncountable due to heterogeneous uranium distribution, high radiation damage, cracks and inclusions, etch quality, and other factors that are typical of zircon on detrital grain mounts. After the grains have been mounted in Teflon, the mounts are polished to expose smooth internal zircon surfaces. One distinctly different approach is that DZFT typically involves making several mounts that then receive different etch times. We recommend at least two mounts

\footnotetext{
${ }^{1}$ In the past many FT labs have used FEP Teflon, which is available in tape form commercially (i.e. Saunders Inc.). In the mid to late 1990's many FT labs switched to PFA Teflon, which is composed of tetraflouroethyleneperflouroalkoxyethene. One problem, is that PFA Teflon has limited commercial availability. For details, see Ontrack, v. 2, n.2, p. 17 (November 1992, available on the internet). PFA Teflon has a higher melting temperature, and is more resistant to chemical attack in the etchant. However, it is more difficult to handle while mounting.
} 
per sample that are then etched for different lengths of time (see Naeser et al. 1987; Garver et al. 2000b; Bernet et al. 2004b), but in cases where the grain-age distribution is very large (i.e. grain ages span 1000 m.y.) then up to six mounts may be required to fully capture the full grain-age distribution (i.e. Meyer and Garver 2000). The reason for the different etch times is that a detrital sample contains a mixture of zircons with different amounts of radiation damage, and therefore different chemical reactivity (or "etchabilities" - discussed below - see Naeser et al. 1987; Garver et al. 2000a; Bernet et al. 2004b). Nevertheless, in most provenance and exhumation studies, grain ages between a few million and several hundred millions of years can be dated (Fig. 3).

Etching. Etching polished mounts is among the most crucial steps in DZFT analysis. Zircon etching is done with a strong acid or base that attacks the polished crystal surface. The increase in crystal disorder in the damaged track is preferentially attacked and the track is fully revealed for optical analysis when etched long enough. Detrital suites typically have a large variation in single-grain radiation damage, which is generally attributed to $\alpha$-recoil damage from the decay of uranium and thorium (see Garver and Kamp 2002). Accumulated $\alpha$-damage increases the chemical reactivity of a zircon, so that highly damaged grains (generally older grains all else being equal) are much easier to etch than grains with little damage. This difference is not trivial and typical etch times can vary by about 3 orders of magnitude (1-100 hr for our lab set up). The etchant should be replaced regularly during the etching process (every 24 to 48 hours), especially when working with impure mounts, to maintain etching efficiency.

Note that the etch formula and etching temperature vary from lab to lab and a useful summary of these different conditions is given in Garver (2003). Here we discuss some general etching characteristics using conditions most commonly employed in labs around the world. This typical set up includes an etchant composed of a $\mathrm{NaOH}: \mathrm{KOH}$ eutectic at $225-230^{\circ} \mathrm{C}$, in a covered Teflon dish heated by a laboratory oven. We are not trying to imply that this is the best approach for etching, but these are the conditions that we are most familiar with. The single biggest variable that affects etch time is temperature (Garver 2003), so temperature control should be well calibrated, and strictly controlled.

Three approaches have been used to attempt to fully reveal tracks in a Teflonmounted mixed suite of zircon. The Muti-Etch technique assures both random selection and optimal etching by repeatedly etching and counting a single mount at regular 
intervals (Hasebe et al. 1993). This method provides an unbiased distribution of grain ages, but is very time intensive and operationally difficult (see Hasebe et al. 1993, p. 124). The Multi-Mount technique optimizes the total range of countable grains by insuring that all grain populations are well etched by etching several mounts over different lengths of times and counting grains from all mounts (Naeser et al. 1987). The principal advantage of this technique is that it quickly and reliably provides the full FTGA spectrum. However, this approach may result in an inadequate quantitative sampling of the FTGA distribution because of the overlap of the ages dated in the individual mounts certain age groups may be over-represented. The Optimal Etch technique attempts to maximize a certain population of grains from a single sample (e.g. Kowallis et al. 1986; Garver and Brandon 1994b). This approach requires that a particular population is optimally etched at the expense of all other populations, and it has largely been used to date the young population of grains.

There is no simple formula for determining etch time required for a suite of samples, but here we offer some general rules that work in our labs using the Multi-Mount technique. To illustrate the general variation in etch times we refer to Figure 4, which shows the relation between etch time, $U$ content, and fission-track age of detrital zircon from a number of rivers that drain the Alps (Bernet et al. 2004a, b). This plot demonstrates that zircon with young cooling ages and low accumulation of radiation damage need longer etch times to reveal countable tracks as discussed above. Recall that zircons with high radiation damage etch much more easily and countable tracks are visible after short etch times. Therefore, a good starting approach is to etch one mount for a few hours, remove from the etchant, clean, and evaluate tracks under the microscope. If the majority of the grains are under-etched, then additional etch-time is needed. We found that in many settings it is good to start with etch times between 8 and 30 hours. The etch time of the second mount can then be selected shorter or longer, depending on the etching response of the first mount. With two mounts, one should attempt to straddle the optimal etch time. When we prepare a series of samples for analysis (20-40 samples), we typically budget about 5-7 days for all etching, well in excess of the 1-2 $\mathrm{hr}$ that would be required to etch a comparable suite of apatite mounts.

A unique situation involves samples with both very young grains mixed with older grains. Typical zircons have uranium concentrations between about 200 and $450 \mathrm{ppm}$ (see Garver and Kamp 2002; Reiners et al. in review). Detrital grains with typical 
uranium concentrations and ZFT ages of less than about 1-3 Ma in age have little radiation damage and require very long etch times (c. $30-100 \mathrm{hr}$ ). These low-damage grains have an etching anisotropy that results in a differential rate of track revelation parallel to c-axis (slower) compared to perpendicular to the c-axis (faster). However, there is an additional problem in that because they are young they may have few if any tracks: it can be difficult to evaluate whether a grain is properly etched if it has no tracks (a zero-track grain) because the quality of the etch is evaluated by most workers by trackpit diameter. If there are no tracks it is difficult to ascertain if the grain has been sufficiently etched. One possible solution to this problem is to etch for a very long time (40-100 hr), and assume that all grains are well etched, and count all grains (even zerotrack grains). In this approach, older grains may be sacrificed due to overetching. If zero-track grains are ignored, the data set will be biased, and not representative of the grain-age distribution in the source region. As such, when evaluating detrital zircon with a population of grains $<1-3 \mathrm{Ma}$, one needs to carefully devise the experimental conditions to capture this difficult-to-etch population.

Counting. Counting tracks in zircon for FT analysis is routine, but for DZFT dating there are a few specific procedural aspects that are unique. At issue here is sample bias, and grain countability. Grains with high spontaneous track densities (track densities $>3 \times 10^{7}$ tracks $/ \mathrm{cm}^{2}$, usually old grains or those with very high uranium concentrations) or metamict grains cannot be dated with the FT method, because individual tracks cannot be differentiated and counted. On the other end of the spectrum, grains with low track densities may be underetched.

In an attempt to avoid further bias and to obtain representative and reliable results only a random selection of countable zircons should be analyzed, from a randomly mixed suite of zircons in the Teflon mount. That approach differs from routine ZFT analysis where one would select representative grains of the best population of grains for dating. Detrital zircon grains should be selected by their countability and not by shape, size, clarity, or other attributes. Therefore, only grains containing well-etched fission tracks should be counted and under-etched or over-etched grains should be omitted. In addition, grains with strong zoning, uneven surfaces, cracks, inclusions, or very small counting areas should not be counted. The crucial aspect of counting is that specific criteria are determined at the onset of analysis and that these criteria are then strictly followed. 
Track-lengths. Measuring track lengths of horizontally confined tracks (HCT) for modeling thermal histories is a standard procedure in apatite FT analysis, but not so for zircon. While several labs do measure track lengths in zircon, routine analysis is hindered by variability in grain-to-grain etch times, which is attributed to variation in alpha damage. Track-lengths measurements have never been reported in DZFT analysis, largely due to the fact that detrital grains have extreme variation in etch times, and therefore single grain measurements are nearly meaningless. Additionally, it is difficult to establish a unique population for a single grain that might have a measurable track length. Note that even with the analysis of detrital apatites, track lengths are rarely done because it is difficult to assign single grains to component populations with distinct thermal histories (see Garver et al. 1999).

\section{Grain-age analysis and data presentation}

The results obtained from DZFT analysis can be evaluated in several different ways, but the goal in each approach is to discriminate populations of cooling ages. First, it is important to determine if any grains are younger than the depositional age of the sample. All the youngest grains would naturally fall into the minimum age group of a detrital sample, which has special significance in many studies. The minimum age is determined either by binomial peak fitting or by $\chi^{2}$ evaluation, and may be of importance in refining the depositional age of the sample or for detecting partial resetting during lowtemperature thermal events (see discussion below). Second, it is common to calculate the mean age of the FTGA distribution, which may be of interested when determining average exhumation rates in exhumational studies. A third approach, which is widely used, is to decompose the distribution of grain ages into individual grain-age components through a number of statistical techniques (e.g. see Brandon 1996 for discussion). Currently available software packages for data analysis and graphical or numeric data presentation include BINOMFIT based on Brandon (1996), POPSHARE from Dunk1 (unpublished), or MACMIX based on the approach of Sambridge and Compston (1994). We prefer a binomial peak fitting routine from Galbraith and Green (1990), which is used in the BINOMFIT program. This approach involves taking the observed grain-age distribution and then decomposing it into major grain-age components or peaks (labeled P1, P2, P3 etc.). 
The full grain-age spectrum and binomial fitted peaks are conveniently presented in histograms, probability density (PD) plots, or radial plots (Fig. 5). If detrital samples of the same stratigraphic age are collected and compared to each other, than it is useful to look for reoccurring peak-age groups (i.e. label P1, P2, P3 and so on, see Table 1 in Bernet et al. 2004b; also see Sircombe and Hazelton 2004). If samples with different depositional ages from a stratigraphic section are presented, than P1, P2, P3 etc. should be assigned just as they occur.

Stewart and Brandon (2004) provide a discussion on the detection limit of the FT method on detrital samples and on how many grains should be counted per sample to identify major grain-age components. It is our experience that counting more than 100 grains per sample does not significantly improve the results and is usually not justified given the amount of time it takes to date 100 grains, but for a different opinion see the discussion by Vermeesch (2004).

\section{INTERPRETATION OF FISSION-TRACK GRAIN-AGE DISTRIBUTIONS}

Once individual grains from samples are dated, results can be placed in geologic context. Before we discuss specific results, we review a few important concepts in the literature that frame the context of detrital peak ages. For a start, one could ask the following questions: are all age components or peaks older than the depositional age and reflect exhumation and cooling in the source area? Is there a volcanic component not related to exhumation-driven cooling? If grains have been derived from an orogenic source, which grains are from reset metamorphic sources, and which grains are recycled from sedimentary cover units? If $\mathrm{P} 1$ in a sample is younger than the depositional age, is that an indication for partial annealing after deposition?

\section{The Partial Annealing zone and Closure of the ZFT system}

Fission tracks in zircon result from the spontaneous fission of ${ }^{238} \mathrm{U}$ and the formation of a track or damage zone in the crystal from these fission events. At elevated temperatures these tracks anneal, which means they shorten and then disappear as fast as they are formed, but at low temperatures all tracks are fully retained. Because detrital zircon in sedimentary strata commonly get buried and heated it is important in any DZFT study to determine if there is any evidence of full or partial FT annealing after deposition. 
To evaluate thermal maturity of sedimentary rocks, we can independently employ techniques such as apatite FT, $(\mathrm{U}-\mathrm{Th}) / \mathrm{He}$, vitrinite reflectance $\left(\mathrm{R}_{\mathrm{o}}\right)$, or conodont coloralteration indices (CAI).

The temperature range below which tracks are retained and above which tracks are lost is commonly referred to as the Partial Annealing Zone (PAZ) (see Wagner and van den Haute 1990). For simplicity many workers refer to an effective closure temperature instead of the partial annealing zone, which represents the temperature of nearly full track retention, and therefore closure of the FT system (after Dodson 1973). Even if this is a rather simplified concept when considering the parameters (time, temperature, cooling rate, radiation damage, pressure etc.) that influence partial and full track retention or resetting in zircon, it is a widely used concept that works reasonably well. In most geological settings zircon has an effective closure temperature of about $240^{\circ} \mathrm{C} \pm 30$ (Brandon et al. 1998; Bernet et al. 2002), but this temperature is sensitive to the rate of cooling and radiation damage in the zircon (Fig. 2; also see Garver et al. 2002; Rahn et al. 2004; Garver et al. 2005). We use the estimates of Brandon and Vance (1992) that suggest the $90 \%$ retention temperature in most cases (or $\mathrm{T}_{90 \%}$ ) is $\sim 240^{\circ} \mathrm{C}$. Likewise, detrital samples that have preserved unreset zircons are assumed to have resided below temperatures (track retention of greater than $10 \%$ or $\mathrm{T}_{10 \%}$ ) of $\sim 175^{\circ}$ to $200^{\circ} \mathrm{C}$ for heating times between 25 and 1 million years (see discussion in Brandon and Vance, 1992). Note that the $\mathrm{T}_{90 \%}\left(\sim 240^{\circ} \mathrm{C}\right)$ corresponds to a depth of about 7.5-8 $\mathrm{km}$ assuming a typical continental geotherm of $30^{\circ} \mathrm{C} / \mathrm{km}$ and an average surface temperature of $\sim 10^{\circ} \mathrm{C}$.

Resetting for any particular grain is largely a function of internal radiation damage, which affects its annealing properties: low-damage grains are more resistant to annealing than high-damage grains (Garver et al. 2005). These end members can be simplified in general conceptual terms: Low-Retentive zircon (LRZ) has a partly disordered crystalline structure, significant radiation damage and a low temperature of annealing (c. 180$200^{\circ} \mathrm{C}$ ). High-Retentive zircon (HRZ), which is nearly crystalline, fully anneals at temperatures in excess of $\sim 280-300^{\circ} \mathrm{C}$. At higher temperatures, all grains are reset provided the sample remains at these temperatures for a geologically significant time $\left(>10^{6} \mathrm{yr}\right)$. Most differential annealing occurs in the range of about 180 to $280^{\circ} \mathrm{C}$. Exhumation of rocks that have been buried and heated to this degree commonly have a population of grains that are fully reset and then a wide range of grain ages that are either partially reset or those that represent provenance ages. Consequently, in a number of 
studies where a young reset population has been identified, it is not clear if the older grain ages are unreset and therefore retain the original provenance information, or if they are partly reset (or both). This is an area of active research, but it is clear that rocks heated to temperatures between 180 and about $220^{\circ} \mathrm{C}$ (the lower end of resetting and partial resetting) have the potential to record both thermal resetting and original provenance information. A crucial factor in this sort of setting is the amount and range in inter-grain radiation damage.

\section{Lag time}

Perhaps the most distinctive aspect of using DZFT analysis on zircon that has not been partially or fully reset after deposition is that cooling ages recorded in the sedimentary detritus can be related to past thermal events in the source terrain. In many cases these cooling events are directly related to uplift and exhumation of source rock, so cooling ages provide a direct link between long-term sediment supply and sediment accumulation. Once a FTGA distribution is determined and peak ages have been fitted, lag times can be determined (Fig. 6). In this case, lag time is defined as the difference between the peak age and the depositional age (Garver and Brandon 1994a; Garver et al. 1999; Bernet et al. 2001), and it represents the lag or difference between closure in the source and deposition in the adjacent basin. In areas of active volcanism, closure occurs during eruption, and erosion may immediately transfer grains to flanking basins, so lag time is nearly zero. In other, non-volcanic cases, rock in the source area is exhumed from depth and the rock passes through a closure isotherm at depth at which time the lag-time clock is set. In this case, the lag time represents the time required for the rock to be exhumed to the surface, eroded, and then the zircon being transported to an adjacent basin. Lag time is then a function of exhumation rate in the source area.

Transformation of lag time to an exhumation rate estimate requires several simplifying assumptions. The basic calculation necessitates that the cooling age can be related to a closure depth, and therefore an estimate of the geothermal gradient and an effective closure temperature is required. In this respect the effect of isotherm advection needs to be considered if exhumation is rapid ( $>1 \mathrm{~km} / \mathrm{m} . \mathrm{y}$. - see Garver et al. 1999). Another simplifying assumption commonly made is that storage of sediment in the orogenic belt is negligible and that sediment is relatively quickly removed from the orogenic belt and deposited in adjacent basins. This latter assumption appears to be valid 
for sediment shed off active orogenic belts (i.e. see Garver and Kamp 2002, Bernet et al. 2004a). In its simplest form, lag time can be converted to an exhumation rate using the relation presented in Figure 7 (see Garver et al. 1999 for details). It is not uncommon to just focus on the shorter lag times (millions to tens of millions of years) because these zircons have been derived from the fastest and most deeply exhuming areas of the source region. Zircons with longer lag-times (tens to hundreds of millions of years) are typically recycled from sedimentary cover units.

\section{Types of lag-time changes}

In principle, three basic lag-time trends can be expected when studying synorogenic samples from a stratigraphically coordinated sequence (Fig. 8). The first trend is a shortening of lag time up-section, which indicates continuous and accelerating exhumation. The FTGA peaks P1, P2 etc. are then regarded as moving peaks, because they become continuously younger at a rate faster than change in depositional age (Fig. $8 \mathrm{~B})$. The second possibility is that peak ages young at the same rate as change in depositional age. In this case, lag time remains constant, but because the peaks young upsection they are also regarded as moving peaks (Fig. 8C). This type of lag time would be characteristic of a constantly exhuming source terrain. The third possibility is that lag time increases up-section, which indicates slowing of exhumation rates (Figure 8D). If peak ages do not change at all up-section, than they are described as static peaks. Such peaks reflect a FT source terrain, which has been rapidly cooled in the past, maybe by fast, episodic exhumation (normal faulting or erosion), and was exhumed slowly since.

\section{EXAMPLES AND APPLICATIONS}

In this section we highlight a few examples of recent studies and applications of DZFT analysis that we think have made an impact on how we look at and analyze data. We present this review to give the reader some suggestions of what can be done with DZFT analysis, and to point out where we think the future lies. Note that this section is not a historical overview, and as such we leave out and ignore some early pioneering work.

\section{Provenance analysis}


Detrital zircon fission-track analysis has a long tradition in provenance analysis (e.g. see review in Hurford and Carter 1991; Carter 1999; Garver et al. 1999). In fact, the earliest use of DZFT was for simple provenance analysis because the technique allows identification of major cooling ages in the source terrain, and this alone is a powerful discriminator of sediment provenance. This approach to provenance analysis -- the analysis of a single mineral phase -- is commonly referred to as a varietal study because a single mineral phase is used to address sediment provenance (e.g. Haughton et al. 1991). Although powerful, varietal studies have limitations because the unique source terrain indicated by the data only pertains to the specific mineral studied, and there may be a host of other lithologies in the source terrain that are essentially unidentified. Therefore, varietal studies are most effective when combined with other sediment provenance techniques aimed at identifying the full provenance spectrum. In considering sediment provenance and zircon source, it is prudent to consider potential source rock lithologies that could have supplied detrital zircon with the shape, color, and morphology in the sample of interest.

Historically, the young populations of grain ages have received the most attention, because they can be commonly ascribed to active processes in the source terrain. For example, if a young population of euhedral ZFT ages is close or identical to the depositional age, then they are likely derived from a volcanic source (Fig. 9A; see Kowallis et al. 1986; Garver and Brandon 1994b; Garver et al. 2000b; Soloviev et al. 2002; Stewart and Brandon 2004). Otherwise, young age peaks in sediment derived from convergent mountain belts without active volcanism reflect rapid exhumation of deepseated metamorphic rocks in the core of the orogen (Fig. 9B; also see Brandon and Vance 1992; Garver and Brandon, 1994b; Garver et al. 1999; Bernet et al. 2001). Zircons from such rocks have been fully reset during regional metamorphism and their cooling ages represent the recent thermal history of the source area. Zircons with older cooling ages are usually derived from partially or non-reset cover units (Fig. 10). Non-reset zircons are therefore recycled and re-introduced into the rock cycle. Here we highlight several examples that demonstrate the utility of this technique in provenance analysis.

European Alps. Geologic settings where abundant bedrock ZFT cooling ages are available allow comparison of DZFT peak ages from modern river samples with the 
bedrock FT age distribution in the drainage area. Such comparative studies were done in the European Alps. DZFT peak ages from rivers that drain the Alps toward their foreland and hinterland, were compared to the dense data set of bedrock ZFT ages available for the Alps (Bernet et al. 2004a,b). These studies helped to improve our understanding of how FTGA distributions can be used to recognize sediment source areas on a local and regional scale, and also demonstrated that detrital samples provide a reliable and representative overview of the bedrock age distribution in their river drainages. Furthermore, it was shown that the provenance signal revealed in the ZFT peak ages is detectable even $>500-1000 \mathrm{~km}$ away from the source and that sediment transport time from source to sink is essentially geological instantaneous in orogenic systems (Bernet et al. 2004a).

In addition to information contained in the ZFT peak ages, another parameter can be evaluated to better constrain zircon provenance is grain morphology. Detailed zircon morphology classifications have been presented in the past (Pupin 1980), but in simplistic terms, euhedral grains are likely to be derived from igneous sources while rounded grains are likely to be derived from sedimentary or meta-sedimentary sources. The FT peak age - grain morphology relation was explored by Dunkl et al. (2001) in a study of the upper Oligocene Macigno Formation in the northern Apennines, Italy. Most sedimentary rocks that occur today in the Apennines were originally derived from the European Alps (e.g. Cibin et al. 2001). Dunkl et al. (2001) showed that some of the zircons belonging to the youngest FTGA component were in fact derived from exhumed metamorphic rocks, while the others were derived from periadriatic igneous rocks in the Alps. The importance of this study lies in the attempt to identify the contribution of igneous zircon in the FTGA distribution of Alpine derived sediment.

In areas where only part of the source lithologies contain zircon, it is sensible to combine DZFT dating with other provenance techniques. For example, Spiegel et al. (2004) used $\mathrm{Nd}$ isotope ratios in detrital epidote to trace provenance from non-zirconbearing basic igneous rocks in the Central Alps in addition to DZFT. Through combination of these two particular provenance techniques these authors were able to propose a detailed picture of sediment source and transport pathways into the foreland basin during the Oligocene and Miocene. This study highlights the important trend towards using multiple provenance techniques to develop a more robust provenance picture. 
Southern Alps of New Zealand. Zircon from either side of the Southern Alps have distinctive FT ages and radiation-damaged-induced color that are distinctive and diagnostic on either side of the orogenic belt. In a study where Recent sediment was collected from drainages with known source rocks, Garver and Kamp (2002) mapped the distribution of FT ages and zircon color (Fig. 11). Color in zircon is a function of radiation damage and rare earth element (REE) content. There are two dominant color series in zircon: the pink series ranges between light pink, pink, rose, red, purple (hyacinth) and black; and the yellow series ranges between pale yellow, straw, honey, brown, and black (i.e. Gastil et al. 1967). The color of the pink series gets reset, and the zircon becomes colorless, between $\sim 250-400^{\circ} \mathrm{C}$. In the Southern Alps zircons can be grouped into three categories (from deepest to shallowest crustal levels): 1) reset FT age reset color; 2) reset FT age - non-reset color; and 3) non-reset FT age - non-reset color, in the order of decreasing temperature ranges (Garver and Kamp 2002). Because uplift and exhumation of the Southern Alps is asymmetric across the range, deeply exhumed rocks occur on the west side, and rocks that have been at shallow crustal levels occur on the east side. This difference is dramatically reflected in the sediment provenance of river sediment. In the west-flowing rivers, $80 \%$ of the zircons are colorless and about $\sim 60 \%$ of the dated grains have FT ages of less than $22 \mathrm{Ma}$. This assemblage represents deeply exhumed rocks that have come from depths of at least $10 \mathrm{~km}$. Quite the opposite occurs on the eastern side of the Southern Alps, where $\sim 50-70 \%$ of the grains have color and almost all FT ages are older than $100 \mathrm{Ma}$ (Fig. 11). This latter assemblage of zircon represents rocks that had been fed laterally into the orogenic system, and these rocks have resided at shallow crustal levels $(<10 \mathrm{~km})$ for about $100 \mathrm{Ma}$. The important point of this example is that not only FT age, but also other aspects of the zircon can be used to locate crustal material with a specific thermal history.

Ecuadorian Andes. Basins flanking the Andes have an excellent record of the uplift and exhumation of the orogenic belt as well as adjacent continental blocks. The basin strata that flank these crustal blocks provide some of the most important information on the movement history of adjacent crustal blocks. It is difficult, however, to determine the source of the basin fill in some cases, because many crustal blocks have geologic similarities. To solve this problem, Ruiz et al. (2004) studied 24 Cretaceous to Tertiary 
samples from strata in the Andean Amazon basin in Ecuador. They recognize several important changes in ZFT grain-age distributions in the stratigraphic sequence. In the lower part of the Cretaceous section they discovered that part of the population consists of relatively old DZFT ages (Paleozoic), in zircons that are characteristically dark and rounded. These zircons occur in sedimentary rocks that have a high ZTR index. Because the ZTR index is high for these samples, they attributed the zircons as polycyclic and derived from the Paleozoic platform cover to the craton. Up-section, they identified an influx of near-zero-lag-time grains that coincide with an influx of heavy minerals with a decrease in the ZTR index and an increase in the amount of kyanite and sillimanite. The DZFT cooling ages in this part of the section are therefore inferred to record Middle to Late Eocene exhumation of a high-grade metamorphic terrane that may have been affected by collision of the Macuchi Arc terrane to the eastern edge of Ecuador. In the Early Miocene, short lag times are attributed to significant volcanic activity in the source region because the heavy mineral assemblage contains euhedral biotite, hornblende, diopside, apatite and idiomorphic zircon. In addition, the ZFT and apatite FT ages are identical, and therefore it is likely that both reflect cooling of volcanic rocks (Ruiz et al. 2004). This study demonstrates the utility of interpreting the DZFT age patterns using supporting provenance information, especially heavy mineral assemblages that can provide crucial clues as to the nature of the source rock.

\section{Dating strata}

In a number of studies FT analysis of detrital zircon has been used to establish maximum depositional ages of poorly dated or undated sedimentary rocks. One approach that is particularly powerful is to date volcanic ash deposits interbedded with a poorly dated sedimentary sequence (i.e. Kowallis et al. 1986), but obviously this approach only works on stratigraphic sequences that have stratified tuffs. There are many sequences with a partial volcanic provenance where a young volcanic component is mixed with detritus from other sources. We focus on this latter setting, in which one needs to rely on the information contained in the detrital constituents of the sandstones that have a heterogeneous provenance. Stratigraphic sequences in these studies where this technique has been applied have several things in common: 1) they have little or no biostratigraphic control; 2) they are thick, monotonous, and commonly internally structurally imbricated; 
and 3) they have a partial provenance from a volcanic center (mainly continental volcanic arc). The strata have few, if any, internal stratigraphic marker horizons.

Naturally, if sandstone has a population of ZFT cooling ages that represent primary cooling in the source region, then deposition of the sedimentary rock must postdate or equal that cooling age. Where this approach has been most useful is in those instances where the source region contains an active volcanic source that contributes a significant fraction of zircons with nearly syndepositional cooling ages to the basin. In our experience, this generally means that the source included a continental volcanic arc, which produces relatively large volumes of sediment, and many of the volcanic rock types are rich in zircon. Because this young age is strictly a limiting age, it has been referred to as a FT minimum age in the literature because the calculated age is the minimum FT component in the grain-age distribution (i.e. Garver et al. 2000b).

Kamchatka - Forearc strata of the Ukelayet Flysch. The thick, deep-water flysch sequences in the Olutorsky collision zone provide a good case study for this approach because the Kamchatka margin has been volcanically active for the last $100 \mathrm{Ma}$, and a tremendous thickness of poorly dated strata have accumulated. Work on a number of these sequences has demonstrated how FT dating of detrital zircon can be used to determine depositional ages of terrigenous sequences in a continental arc setting (Garver et al. 2000b; Shapiro et al. 2001; Soloviev et al. 2001, 2002). These researchers carried out detailed analyses of Cretaceous to Eocene turbiditic sandstone along most of the Kamchatka margin and in the southern Koryak upland farther north. They determined that the youngest age component of each of their samples was comprised mainly of euhedral and colorless zircon inferred to be first-cycle volcanic zircons. These first-cycle zircons are inferred to have been derived from active magmatism in the nearby OkhotskChukotka continental arc and the Western Kamchatka-Koryak Volcanic belt between 88 and $\sim 44 \mathrm{Ma}$. This young population of cooling ages constrains depositional ages in this 10-km-thick package of uniform and monotonous turbidites (Fig. 12). Zircons in the second age component, P2, were associated with continuous exhumation and cooling of basement rocks to Okhotsk-Chukotka continental arc. While many of the dated sandstones are from sequences that have no fossils, one study area focused on dating detrital zircon from sandstones that had age control from nannofossils in interbedded shales. Without exception, the ZFT minimum ages coincided with the age constraints 
provided by nannofossils (Shapiro et al. 2001; Soloviev et al. 2001). Note that for the most part, these sandstones are quartzo-feldspathic and arkoses with a relatively minor amount of volcanic detritus (see Shapiro et al. 2001). Despite this lack of obvious volcanic detritus, it is certain that the grains are volcanic (or high level) because those in the young population have $\mathrm{U} / \mathrm{Pb}$ and $\mathrm{ZFT}$ ages that are statistically indistinguishable (Hourigan et al. 2001).

Olympic Subduction Complex, Cascadia forearc. The Olympic subduction complex (OSC) comprises much of the uplifted and exhumed part of the subduction complex to the Cascadia subduction wedge (Brandon et al. 1998). Sedimentary units in the subduction complex are thick, structurally imbricated, and mostly monotonous sequences of Tertiary deep-water turbidites. DZFT dating of these units has fundamentally altered our understanding of the age-distribution of accreted units in the subduction complex and flanking strata (Brandon and Vance 1992; Garver and Brandon 1994a; Brandon et al. 1998; Stewart and Brandon 2004). Dating of sedimentary units of the central part of the OSC has shown that many of the units have significant populations of cooling ages that fall at 43,57, and $74 \mathrm{Ma}$ and these are related to rapidly cooled crustal blocks in the hinterland, behind the Cascade arc. These populations have the same age regardless of depositional age of the sandstone, and as such they are referred to as static peaks (Fig. 8). The sandstones also have a minor population of young ages that is variable and appears to be very close to depositional age, where depositional age is constrained. The authors referred to this young peak as a moving peak because it becomes younger with time (Fig. 8). This young moving peak was inferred to represent material from the syn-contemporaneous Cascade arc.

More recent work in the Olympic Subduction Complex confirms earlier conclusions. Stewart and Brandon (2004) conducted a detailed examination of the siliciclastic, lower Miocene "Hoh Formation" of the Coastal OSC. They analyzed 34 sandstone samples and 2 volcanic ash layers of the coastal OSC, and used the young peak age to show that most of the strata are Lower Miocene. They note that most sandstones in the Hoh Formation are variable in composition, but most fall between lithic arkoses or lithic wackes, with volcanic lithic fragments. The young population of cooling ages is inferred to represent material from the syn-contemporaneous Cascade arc, and in a few instances they were able to show that the young population was the same as the paleontologically 
determined depositional age. They nicely summarize the reasoning behind the assumption that P1 (young peak age) can be used as a proxy for depositional age, which is mainly focused on an analysis of those units that have fossil control.

\section{Exhumation studies}

Exhumation studies are aimed at gaining a better understanding of the long-term evolution and thermal structure of an orogen, and determining the rate of exhumation in known source regions. Convergent mountain belts, such as the European Alps, the Southern Alps of New Zealand, or the Himalayas have been successfully studied using this analysis, largely because these mountain belts lack significant volcanic activity, so most, if not all, of the cooling ages are related to tectonic or erosional exhumation and not igneous activity. It is difficult to study exhumation of orogenic systems with significant igneous activity, such as continental arcs, because the thermal structure of the crust is affected by both exhumation and igneous heating.

There are several practical considerations one needs to bear in mind when using the sediment record to understand orogenic exhumation. Recall the objective here is to use cooling ages of zircons in basin strata to make inferences about the long-term evolution of the source area. The typical approach is to isolate and analyze detrital zircon from a number of different stratigraphic levels so that the nature of the source through time can be evaluated. Individual zircons in basin strata may have an uncertain provenance and the inferences need to be made as to original source rock. Additionally, almost all orogenic systems produce a wide variety of ZFT cooling ages, so as discussed above, cooling age populations need to be carefully isolated. Finally, one needs to understand sediment transport in the basin and how that sediment transport might have changed in the basin.

In general, exhumation studies using DZFT ages are based on understanding a prominent peak-age distribution, determining the lag time of that peak age and an inferred exhumation rate, and then evaluating how that exhumation rate changes with time, as described above. Samples should be collected from strata that are stratigraphically well dated: if they are not, the lag time, and hence the calculated exhumation rate, will have a high uncertainty. The possible effects of sediment storage need to be evaluated as well. Significant sediment storage, which may be characteristic 
of moderate to slow exhumed systems, increases lag time and therefore calculated exhumation rates would be too slow if storage time is significant (on the order of millions of years). However, in most studies, where source-rock exhumation is on the order of $200 \mathrm{~m} / \mathrm{m}$.y. or faster, it is assumed that sediment storage is insignificant (i.e. Bernet et al. 2001, Bernet et al. 2004a).

Himalayas. The earliest studies aimed at understanding orogenic exhumation were focused on the sedimentary apron at the foot of the Himalayas (Zeitler et al. 1986; Cerveny et al. 1988). In fact, the work by Zeitler et al. (1986) and Cerveny et al. (1988) was ground breaking and of unparalleled importance for DZFT analysis. These authors took the method from being merely useful for provenance analysis to being a powerful tool to study the long-term evolution of convergent mountain belts. In these studies, DZFT analysis was used to improve the understating of exhumation in the Nanga Parbat region in the northwestern Himalayas. The authors analyzed samples from the modern Indus River, as well as from stratigraphic sections of the Miocene to Pliocene Siwalik Formations in Pakistan. They concluded that exhumation rates of $300 \mathrm{~m} / \mathrm{m}$.y. and above have existed at least in part of the Himalayan zircon source areas (Zeitler et al. 1986). Cerveney et al. (1988) came to the conclusion that high exhumation rates and high relief were common features in the Nanga Parbat-Haramosh Massif over the past $18 \mathrm{Ma}$. Their conclusion is based on the occurrence of young zircons, within1-5 m.y. of the depositional age in each of their stratigraphic samples and in modern Indus River sediment.

It is interesting to reconsider the data from Cerveny et al. (1988) using the lag-time concept outlined above. The results of this re-analysis indicate that lag time becomes shorter up-section for both P1 and P2 age components (moving peaks) in the Indus River and Siwalik sediments from the Middle Miocene to the Recent (Fig. 13). This up-section change suggests that this part of the Himalayas has been in a constructional phase with increasing relief and accelerating exhumation rates since the Miocene.

British Columbia Coast Range, Canada. One of the earliest examples of DZFT analysis applied to long-term source rock exhumation was from a well-dated stratigraphic section of the Tofino basin in Washington State and British Columbia, 
which records the erosional exhumation of the British Columbia Coast plutonic complex that makes up most of the Coast Range (Garver and Brandon 1994b). Eight stratigraphically coordinated samples ranging in age from Middle Eocene to Miocene (40 to $19 \mathrm{Ma}$ ) were analyzed using this approach. Known ZFT cooling ages in the modern Coast Plutonic Complex (CPC), the incidental source of the sediment, were also considered in the analysis. This combined record of cooling ages allowed for interpretation of a $\sim 40$ m.y. record of lag times that are interpreted to represent the emergence of the CPC and continued exhumation through time. These lag-time data suggest a nearly constant long-term average exhumation rate of $250 \mathrm{~m} / \mathrm{m}$.y., a moderate exhumation rate.

In this study, FT ages were interpreted in the context of sediment provenance, paleocurrents, and basin infill history, and there are two distinctive aspects of the sediment provenance in this study. The first is that the oldest sample was derived from metamorphic rocks of the nearby Leech River Schist (not the CPC), but the more quartzo-feldspathic facies were derived from plutonic rocks of the CPC and adjacent cover rocks. The second aspect is that the first detritus shed off the uplifted and exhuming CPC included old basin deposits (Cretaceous), which resulted in a complicated distribution of grain ages, and a lithic feldspathic sandstone composition. The important point of these two examples is that the sediment provenance of this basin sequence plays a crucial role in interpreting the significance of the DZFT ages.

European Alps. The Alps are an excellent mountain belt for exhumation studies because they have evolved without significant volcanism since the Oligocene. Because the orogen lacks significant igneous heating, samples collected from controlled stratigraphic sections of synorogenic sediment of foreland and hinterland basins provide insight into the long-term exhumation history. One of the most important observations in recent studies in the Alps is the up-section evolution of ZFT peak ages (Spiegel et al. 2000; Bernet et al. 2001; Bernet et al. in press). The peak ages change at the same rate as the depositional age, and are therefore described as moving peaks (Fig. 14), and they indicate relatively fast, continuous exhumation.

Analysis of the youngest peak age in each sample shows that exhumation rates of the fastest exhuming areas in the Alps have remained relatively constant since the Early 
Miocene at long-term average rates of about $700 \mathrm{~m} / \mathrm{m} . \mathrm{y}$. Continuous P2 lag times give exhumation rates of 300-400 m/m.y. (Bernet et al. 2001), which are in the range of longterm erosion rate estimates for the Alps in other studies (e.g. Schlunegger et al. 2001; Kuhlemann et al. 2002). Nevertheless, the interpretation of a long-term exhumational steady state of the European Alps by Bernet et al. (2001), on the basis of DZFT lag times, is controversial. This work initiated a debate on the long-term evolution and steady state of mountain belts in general and the Alps in particular, and led to the increased use of the lag-time concept to understand orogenic exhumation. While exhumation rates determined by Bernet et al. (2001) agree with estimates from other workers (e.g. Clark and Jäger 1969; Hinderer 2001), the exhumational steady-state interpretation is in apparent conflict with a dramatic increase in sediment yield from the Alps since the Pliocene as predicted from sediment budget calculations (Kuhlemann 2000) or apatite FT analysis in drill cores from the North Alpine Foreland basin (Cederbom et al. 2004). Nonetheless, additional work has shown that the same steady lag-time trend and same long-term average exhumation rates can be observed in the Alpine foreland as in the hinterland (Fig. 14), because the Alps are a doubly vergent orogenic wedge that has shed zircon with young cooling ages to both sides of the mountain belt (Bernet et al. in press).

\section{Dating low-temperature thermal events and strata exhumation}

We described situations above where detrital zircon occur in sedimentary basins, but in some cases samples may come from deeply buried and heated sequences that may possibly be partially or fully reset. Partial resetting of mixed suites of zircon is most conspicuous when sedimentary zircons with a wide range of radiation damage are brought to elevated temperatures (c. $200^{\circ} \mathrm{C}$ ), and then allowed to cool. Partially reset samples have LRZ that were partially of fully annealed and HRZ that were not annealed after deposition. In this case, cooling ages are not concordant, and the young population, which is younger than depositional age, corresponds to cooling following the thermal event. Full annealing of both LRZ and HRZ results in cooling ages that are concordant, but requires relatively high temperatures $\left(>300^{\circ} \mathrm{C}\right.$ and above). This property of partial annealing can be used to date low-temperature thermal events $\left(<300^{\circ} \mathrm{C}\right)$ and the exhumation of strata (see full discussion in Garver et al., 2005). In this section, we draw attention to several studies that used post-depositional partial resetting of detrital zircon to date low-temperature thermal overprint and exhumation of heated sedimentary rocks. 
Olympic Mountains, Western USA. Deeply exhumed strata in the core of the Olympic Mountains were first deposited in the offshore accretionary complex, then accreted into the Olympic subduction complex, and finally exhumed to the surface by erosional processes. FT analysis of detrital zircon from Cenozoic sandstone in the exhumed core of the Olympic Subduction Complex (OSC) and in flanking units, define the timing of deposition, subduction accretion, and exhumation in the core of the Olympic Mountains (Brandon and Vance 1992). Detrital zircons have reset FT ages of $\sim 14 \mathrm{Ma}$ in the core of the OSC, and this cooling age is related to post-metamorphic cooling driven by erosional exhumation. Samples from unreset sandstone units that flank the main reset area have preserved their original undisturbed grain-age distributions with several distinct grain-ages populations related to episodes of source terrain cooling (see above, Brandon and Vance 1992).

The reset zone in the center of the OSC represents the youngest and most deeply exhumed part of the OSC. This region also coincides with the area of the highest topographic relief in the Olympic Mountains. Subaerial erosion started at $\sim 12 \mathrm{Ma}$, when the OSC first became emerged. Since then, roughly $12 \mathrm{~km}$ of rock has been removed from the core of the OSC, resulting in a long-term exhumation rate of $\sim 1000 \mathrm{~m} / \mathrm{m}$.y. (Brandon et al. 1998). All grains in samples from the core were not fully reset during metamorphism, despite the fact that they achieved the highest temperatures of any rocks exposed in the accretionary complex. However, the young fully reset population is clearly geologically meaningful, and therefore the authors report FT minimum ages, which is the youngest population of grains. The FT ages for single grains range in age from 6-36 Ma, but they are resolvable into young peak ages (P1) between 13 and 14.5 $\mathrm{Ma}$, and older peak ages (P2) between about 17 and 25 Ma that are defined by about half the grain ages. Assuming monotonic cooling, they estimate that these samples reached peak temperatures of $239^{\circ} \mathrm{C}$ and cooled at rates between 15 and $20^{\circ} \mathrm{C} / \mathrm{m} . \mathrm{y}$. (see Brandon and Vance 1992 and Brandon et al. 1998 for details).

Taiwanese Alps. Detrital zircon from metamorphosed Eocene to Miocene sedimentary rocks of the Taiwanese Alps record the progressive north-to-south exhumation that has brought meta-sediments in the axial spine of the range to the surface 
as a consequence of the ongoing oblique collision between the Luzon arc and the Asian mainland (Liu et al. 2001; Willett et al. 2003). These studies show that zircons in the Central Range of the Taiwanese Alps are largely reset with minimum ages of 0.9-2.0 Ma. Such young minimum ages reflect resetting of the least retentive of the zircons in the sample distribution. More retentive zircons remain unreset or partly reset and these occur in most of the samples from the Central Range, and therefore it is unlikely that these samples attained temperatures in excess of $280-300^{\circ} \mathrm{C}$ (i.e. see Brandon and Vance 1992).

In contrast, ZFT ages from the Western Foothills and southern Taiwan are consistently older than depositional ages of host strata therefore the grains still retain cooling ages of their source region. Like the Olympics, these unreset samples occur around the deeply exhumed samples and represent rocks with a shallower depth of burial. This restricted spatial extent of reset minimum ZFT ages indicates limited exhumation of the Western Foothills belt and supports an interpretation of the southward propagation of the collision zone (Willett et al. 2003).

Peruvian Andes. The Cordillera Huayhuash and surrounding areas of the Puna surface of this part of the high Andes are underlain by Cretaceous quartzites that have been subjected to moderate temperatures for long intervals of time and therefore they record the effects of reheating and prolonged cooling of high-damaged zircon (Garver et al. 2005). Bedrock is dominated by folded Mesozoic miogeoclinal rocks unconformably overlain by mid-Tertiary volcanics intruded by late Tertiary granitic rocks and silicic dikes. In areas where the rocks are completely unreset, quartzites have late Paleozoic cooling ages and therefore by the time they were heated in the Tertiary, zircons had at least 200 to 300 m.y. of accumulated radiation damage, much more, on average, than the two examples highlighted above.

These Lower Cretaceous quartzites have ZFT ages with a wide range of cooling ages, but almost all are younger than depositional age of the host strata, so resetting has been pervasive (Fig. 15). In this study (Garver et al. 2005), the authors identify LRZ and HRZ depending on single-grain susceptibility to annealing of fission tracks. They discovered that most LRZ have reset ages at c. $27 \mathrm{Ma}$, and $63 \mathrm{Ma}$ in rocks that probably never attained temperatures higher than c. $180-200^{\circ} \mathrm{C}$ (based on vitrinite reflectance values). In this case, the young peak age of $27 \mathrm{Ma}$ can be attributed to cooling following 
a period of intrusion and widespread volcanism, so there was a readily available heat source at this time. It is not clear if the $63 \mathrm{Ma}$ ages represent a thermal event or if they represent partially reset grain ages that are meaningless with respect to the geologic history of this area.

Hudson Valley, Eastern USA. Lower Paleozoic strata of the lower Hudson Valley in New York State were deposited and shallowly buried (c. $5 \mathrm{~km})$ prior to rifting of the North Atlantic and associated rift-basin formation in eastern North America. Detrital zircons from the Ordovician Austin Glen Formation and the Silurian Shawangunk Conglomerates have a wide spectrum of cooling ages, most of which are younger than depositional ages, so resetting is widespread (Garver et al. 2002). Cooling ages can be divided into three populations: a) reset in the Early Jurassic ( $\sim 185 \mathrm{Ma})$; b) reset or partially reset in the late Paleozoic (c. 275 to 322); and; c) unreset to partially reset in the early Paleozoic (Figure 16). These FT data clearly show that the Shawangunk Cg. experienced an Early Jurassic thermal event, and it would appear that only the most damaged grains were reset. Rocks in this part of the Hudson Valley experienced temperatures of $\sim 180-220^{\circ} \mathrm{C}$, based on published vitrinite reflectance, CAI, and illite crystallinity values. These data suggest that the zircons were reset during Early Jurassic heating and an elevated geothermal gradient of $\sim 50^{\circ} \mathrm{C} / \mathrm{km}$ (see Garver et al., 2002).

Shimanto Belt, SW Japan. Strata of the Shimanto Belt represent an exhumed accretionary complex that accumulated at the leading edge of the Eurasian plate. Similar to the Olympic Subduction Complex discussed above, these rocks are part of a thick imbricated package of sedimentary rocks deformed in a subduction setting. These strata include sandstones with a continental provenance, and zircons from these sandstones have had a wide range of grain ages prior to burial and heating. Resetting of detrital zircon in strata in the Kii and Kyushu regions showed the spatial variability and timing of exhumation in this part of the accretionary complex (Hasebe and Tagami 2001).

The Kii region provides important insight into the effects of widespread thermal resetting of detrital zircon. This region consists of three main belts of interest (inboard to outboard): Ryoke, Sambagawa, and Shimanto, which show widespread resetting, with almost none of the samples passing $\chi^{2}$, suggesting heterogeneous annealing throughout the belt. Several end members are represented in the data. Some samples are from 
psammatic schists heated to greenschist conditions, and these have a range of grain ages younger than depositional age but still fail $\chi^{2}$. Others are from sandstones with grain-age distributions that are nearly representative of provenance ages, and therefore have not been heated to any great degree. The general interpretation is that most of these rocks have been heated to well within the zircon PAZ, but the crucial question is the temperature limit of this heating.

The widespread resetting of most samples resulted in ZFT ages with a young population (c. 55-75 Ma) that can be interpreted as the time of maximum burial and heating. Older component ages, some of which are younger than depositional age and some older than depositional age, cannot be interpreted in any geologically meaningful way. It is important to note that virtually all samples that have been heated and reset, still fail $\chi^{2}$, which suggests the original population of grain ages had heterogeneous internal radiation damage. Some of these grains must have been quite resistant to annealing: in the Sambagawa belt ZFT ages fail $\chi^{2}$ but Ar-Ar muscovite ages are reset and the rocks have been metamorphosed to greenschist facies. This setting is instructive because it seems that annealing even at relatively high temperatures produces a wide range of grain ages that reflect heterogeneous annealing due to variation in radiation damage.

\section{Combination with other isotopic dating techniques}

If a DZFT age distribution is useful for understanding sediment provenance, dating strata, and exhumation studies, then it is only logical to assume that multiple geochronometers on the same mineral assemblage or multiple dating of the same grains provide an even deeper and more detailed understanding of the source region. Technical and financial issues are the most significant with respect to why this multi-dating approach hasn't been used more often, but it seems likely that these approaches will see greater use in the future due to methodological advances. Here we briefly highlight a couple of different approaches that should see widespread use in the future.

Multi-cooling studies (FT on two phases). Combining apatite and ZFT analysis of detrital grains from the same sandstone can be used to reconstruct the time temperature history of a source region provided the grains are derived from the same source rock (Lonergan and Johnson 1998). This approach was used to reconstruct the exhumation history of the Betic Cordillera, in southeastern Spain (Lonergan and Johnson 1998). An 
important aspect of this study was that they analyzed apatite and zircon from the same samples collected from synorogenic sediment. They showed that the structurally highest rocks of the Malaguide Complex cooled relatively slowly during the latest Oligocene (Aquitanian), while deep-seated metamorphic units of the Alpujarride complex experienced rapid cooling of up to $300^{\circ} \mathrm{C} / \mathrm{m}$.y. between the Burdigalian to Langhian (c. 15 to $20 \mathrm{Ma}$ ). This change in cooling rate coincides with a change from erosional exhumation to predominantly tectonic exhumation (normal faulting) starting at $21 \mathrm{Ma}$. Tectonic exhumation is related to a phase of orogenic extension in the internal parts of the mountain belt. Heavy mineral analysis on the same rocks shows an increase in metamorphic minerals (i.e. blue sodic amphibole and $\mathrm{Mg}$-rich chloritiods) since $\sim 18 \mathrm{Ma}$.

There are several complexities associated with this approach. These authors attempted to measure track lengths on the detrital apatite, but too few tracks were measured for a meaningful analysis. In this case, and in the case of most detrital apatite studies, it is important to ascertain which cooling age population the grain belongs to if a track length is measured. Otherwise track-length measurements will be nearly useless if they represent a mix of populations. Another complication is that the relative precision of single zircon ages is about 10 times better than apatite, so fitted peak ages tend to be correspondingly less precise. This lack of precision for the apatite system complicates exhumation estimates (discussed in Garver et al. 1999). In sum, this approach is excellent for those cases where both apatite and zircon are derived from the same source rock, most commonly a granitic source terrane, and in those cases where the change in cooling rate is relatively.

Fission-track, U/Pb, and Helium dating on detrital zircon. A natural marriage of analytical techniques for zircon dating is $\mathrm{U} / \mathrm{Pb}$ dating and FT dating of single crystals so that both the crystallization age and the cooling age can be determined (i.e. Carter and Moss 1999; Carter and Bristow 2000, 2003). One of the limiting factors in this sort of analysis is the physical handling of single grains, and the fact that ZFT is partly destructive and $\mathrm{U} / \mathrm{Pb}$ analysis by TIMMS is fully destructive. Advances in (U-Th)/He dating allows for dating of single zircon grains (see Reiners et al., in review). Some of the analytical challenges have disappeared with the routine use of the less destructive 
$\mathrm{U} / \mathrm{Pb}$ determination by SHRIMP analysis and Eximer LA-ICPMS (i.e. see Reiners et al., in review). In this regard, the future is bright for double- and triple-dating techniques.

$\mathrm{U} / \mathrm{Pb}$ and FT dating on a detrital suite from the Khorat Basin in Thailand, helped refine the identification of source rocks by providing cooling age and crystallization ages (Carter and Moss 1999; Carter and Bristow 2000, 2003). In these papers, Carter, Moss, and Bristow argued that determining provenance of zircon solely based on either fissiontrack or $\mathrm{U} / \mathrm{Pb}$ dating would lead to ambiguous identification of source terrains. In early analyses with just FT ages, it was not clear if the FT ages represented rock formation ages (volcanic ages) or cooling ages of metamorphic rocks (exhumation ages). Likewise, interpretation of $\mathrm{U} / \mathrm{Pb}$ data had the problem that crystallization ages can only vaguely be assigned to general source regions but not to distinct source areas, largely because of the propensity of zircon to survive multiple recycling.

The approach to solving this problem in the Khorat Basin was to first analyze two aliquots of zircon from the Mesozoic Phra Wihan Formation, one with the fission-track method and one with the U/Pb method (Carter and Moss 1999). Grains dated with the FT method were removed from their Teflon mounts and dated with the $\mathrm{U} / \mathrm{Pb}$ method using an ion probe (SHRIMP). FT ages from aliquot one showed two main age components at $114 \pm 6 \mathrm{Ma}$ and $175 \pm 10 \mathrm{Ma}$. The $\mathrm{U} / \mathrm{Pb}$ ages from aliquot two revealed five main age components. Removal of the grains from the Teflon mount is required because the ion probe requires a high-quality Au-coat that is hard to achieve with a grain embedded in Teflon. These new $\mathrm{U} / \mathrm{Pb}$ ages of the zircons from aliquot one were representative of the ages from each of the five main $\mathrm{U} / \mathrm{Pb}$ age components. Thus, these results demonstrated that almost all FT ages of zircon from the Phra Wihan Formation are cooling ages related to exhumation of metamorphic rock and not rock formation ages or volcanic eruption ages.

The combination of isotopic dating techniques is an important trend in lowtemperature thermochronology that promises to dramatically improve our understanding of source rock evolution. This development comes at the advent of routine (U-Th)/He (herein ZHe) dating of detrital zircon, which compliments DZFT (see Reiners et al., in review). In effect, ZHe dating, like ZFT, provides a low-temperature cooling age (c. $180^{\circ} \mathrm{C} \mathrm{cf.} 240^{\circ} \mathrm{C}$ ), and therefore this approach can also be effectively combined with $\mathrm{U} / \mathrm{Pb}$ dating to address similar source regions as discussed above (see Reiners 2005). For 
example $\mathrm{ZHe}$ dating and $\mathrm{U} / \mathrm{Pb}$ dating done on the same single zircon grains from the Jurassic Navajo sandstone in the southwestern United States allowed a robust interpretation of the source region (Rahl et al. 2003). These authors showed that zircons in the Navajo sandstone were not locally derived from western North America but more likely came from the Appalachians and had crossed the North American continent to be deposited in the southwest.

\section{CONCLUSIONS}

In this chapter we provide an introduction to DZFT analysis. We gave some practical and analytical considerations concerning sample and data handling, and showed examples of fission-track dating of detrital zircon. These examples include: a) determining sediment provenance and source rock characterization; b) dating strata; c) establishing exhumation histories of orogenic belts; and d) dating low-temperature thermal events. We also provided a series of examples of these main applications. The interested reader can find the associated publications of these applications in the reference list to obtain further information. We conclude with a summary of main points and the potential for future research directions.

1) The revelation of fission tracks in zircon is routine, but challenges remain with respect to etching detrital suites of zircons. Most natural suites of zircons have a wide range of radiation damage, and therefore a wide range of chemical reactivity that is manifested in different etch times. There is a need for studies aimed at quantifying the etch response associated with varying degrees of chemical reactivity (i.e. Garver, 2003). A number of strategies have evolved to fully reveal tracks in a detrital suite of grains with a wide range of etchabilities, we use the multi-mount technique, but there are other approaches that might give a full qualitative representation of grain ages. Particularly difficult are those suites that contain grains $<2-5 \mathrm{Ma}$, because these have a relatively low chemical reactivity.

2) While the general bounds for thermal annealing of zircon are well known. Most laboratory studies have focused on annealed zircon with induced tracks and little to no radiation damage. On the other hand, most studies of the thermal limits of natural fission tracks involve grains that have a moderate level of radiation damage, and they predict 
annealing temperatures that are somewhat lower. It is clear that the main difference is radiation damage, which lowers the effective closure temperature (Rahn et al. 2004). In light of this situation, it seems clear that more studies are needed to quantify the effective closure temperature of monotonically cooled zircon with low, moderate, and high levels of radiation damage. Essentially this approach involves gaining a better understanding of how grains with different damage become reset and fully annealed in different temperature-time conditions. This avenue of research includes understanding the stability of fission tracks in moderately warm settings $\left(150-200^{\circ} \mathrm{C}\right)$, where it seems clear that full resetting of highly damaged grains can occur. This finding has important implications for what we would except in terms of reset grains in basins and other settings where strata are warmed. We also need a better understanding of how and why some grains appear to retain tracks even at relatively high temperatures as seen in the Taiwan Alps and the Olympics. In these settings, the fully reset population clearly gives geologically significant ages, but it is not clear why particular grains become fully reset and others don't.

3) DZFT analysis is most powerful when combined with other provenance techniques and should not be limited only to isotopic dating methods. The combination with conventional sediment petrography, heavy mineral and geochemical analysis, or the relatively new SEM-CL of quartz, can provide a detailed picture of an evolving source terrain. We are confident that DZFT analysis will be more and more applied in connection with other techniques in the future, while it also retains its value as a standalone tool.

4) DZFT has made important contributions to understanding sediment provenance and the exhumation of source terrains. While the potential and utility of this technique has been explored in a number of publications, it is clear that there is wide scope for future studies aimed at high-resolution evaluation of source rock exhumation. Important is a full characterization of sediment provenance and changes in sediment transport in the basin. However, once stratigraphic sections are well characterized, exhumation can be evaluated. Future studies using double dating of low temperature thermochronometers (ZHe and ZFT) will provide high resolution cooling histories of now-eroded orogenic belts. 
5) The combination of ZFT dating with $\mathrm{ZHe}$ or $\mathrm{U} / \mathrm{Pb}$ dating allows for a full characterization of source terrains. So far these double (and triple) dating schemes are not routine and will clearly improve with time as methodological challenges are overcome. The application of Eximer LA-ICP-MS to U/Pb dating is a significant improvement in this respect, because it allows analyzing many grains quickly and inexpensively. The future lies in those studies where a creative approach in combining these techniques allows new insights into poorly understood orogenic belts and poorly resolved tectonic settings.

\section{ACKNOWLEDGEMENTS}

We want to thank the editors P. Reiners and T. Ehlers for inviting us to write this chapter. We acknowledge useful discussions, paper reviews, and electronic discourse we have had over the years with P.A.M. Andriessen, A. Carter, M. Brix, M.T. Brandon, I. Brewer, D. Burbank, A. Gleadow, R.L. Fleischer, B. Fügenschuh, N. Hasebe, J. Hourigan, N. Hovius, A. Hurford, P.J.J. Kamp, B. Kohn, B. Kowallis, N. Naeser, C.W. Naeser, L. Nasdala, J. Rahl, M.K. Rahn, B.C.D. Riley, P.W. Reiners, D. Seward, E. Sobel, C. Spiegel, R.J. Stewart, A.V. Soloviev, T. Tagami, S.N. Thompson, J.A. Vance, P. van der Beek, B. Ventura, G-C. Wang, G. Xu, and M. Zattin. We would also like to thank students over the years who have made DZFT part of their thesis work which is partly summarized in this paper in some form or another: A. Bartholomew, M.E. Bullen, A.J. Frisbie, S.R. Johnston, J.R. Lederer, N.M. Meyer, B.R. Molitor, M.J. Montario, S. Perry, B.C.D. Riley, C.R. Schiffman, S. J. Shoemaker, and L. J. Walker. Support for part of this research was provided by the US NSF grants EAR 9911910 (Kamchatka) and EAR 9614730 (New Zealand) (both to Garver), as well as by a James Dwight Dana Fellowship (Yale University) and a Marie Curie Fellowship (European Union) (both to Bernet). This manuscript profited from detailed reviews by Andy Carter and Massimilliano Zattin, which we gratefully acknowledge.

\section{REFERENCES}

Bernet M, Zattin M, Garver JI, Brandon, MT, Vance, JA (2001) Steady-state exhumation of the European Alps. Geology 29:35-38 
Bernet M, Brandon MT, Garver JI, Reiners PW, Fitzgerald PG (2002) Determining the zircon fission-track closure temperature. GSA Cordilleran Section, $98^{\text {th }}$ annual meeting, Abstract with Programs 34:18

Bernet M, Brandon MT, Garver JI, Molitor BR (2004a) Downstream changes of Alpine zircon fissiontrack ages in the Rhône and Rhine rivers. J Sed Research 74:82-94

Bernet M, Brandon MT, Garver JI, Molitor BR (2004b) Fundamentals of detrital zircon fission-track analysis for provenance and exhumation studies with examples from the European Alps. In Bernet M, Spiegel, C (eds) Detrital Thermochronology - Provenance Analysis, Exhumation, and Landscape Evolution of Mountain Belts. GSA Spec Pub 378:25-36

Bernet M, Brandon, MT, Garver JI, Balestieri, ML, Ventura, B, Zattin, M (2005) Exhuming the Alps through time: Clues from detrital zircon fission-track ages. Am J Sci (in press)

Brandon MT (1996) Probability density plot for fission track grain-age samples. Radiation Measurements 26:663-676

Brandon MT, Vance JA (1992) New statistical methods for analysis of fission track grain-age distributions with applications to detrital zircon ages from the Olympic subduction complex, western Washington State. Am J Sci 292:565-636

Brandon MT, Roden-Tice MK, Garver JI (1998) Late Cenozoic exhumation of the Cascadia accretionary wedge in the Olympic Mountains, northwest Washington State, GSA Bull 110:985-1009

Carter A (1999) Present status and future avenues of source region discrimination and characterization using fission-track analysis. Sed Geol 124:31-45

Carter A, Moss SJ (1999) Combined detrital-zircon fission-track and U-Pb dating: A new approach to understanding hinterland evolution. Geology 27:235-238

Carter A, Bristow CS (2000) Detrital zircon geochronology: Enhancing the quality of sedimentary source information through improved methodology and combined $\mathrm{U}-\mathrm{Pb}$ and fission-track techniques. Basin Research 12:47-57

Carter A, Bristow CS (2003) Linking hinterland evolution and continental basin sedimentation by using detrital zircon thermochronology: a study of the Khorat Plateau Basin, eastern Thailand. Basin Research 15:271-285 
Cederbom CE, Sinclair H, Schlunegger F, Rahn M (2004) Climate-induced rebound and exhumation of the European Alps. Geology 32:709-712

Cerveny PF, Naeser ND, Zeitler PK, Naeser CW, Johnson NM (1988) History of uplift and relief of the Himalaya during the past 18 million years: Evidence from fission-track ages of detrital zircons from sandstones of the Siwalik Group. In Kleinspehn K, Paola C (eds) New perspectives in basin analysis. Springer-Verlag, New York, p 43-61

Cibin U, Spadafora E, Zuffa, GG, Castellarin A (2001) Continental collision history from arenites to episutural basins in the Northern Apennines, Italy. GSA Bulletin 113:4-19

Clark SP, Jäger E (1969) Denudation rate in the Alps from geochronologic and heat flow data. Am J Sci 267:1143-1160

Deer WA, Howie RA, Zussman J (1992) An Introduction to the Rock-Forming Minerals. 2nd edn., Longman Scientific and Technical, Essex, England

Dodson MH (1973) Closure Temperature in Cooling Geochronological and Petrological systems. Contrib Mineral Petrol 40:259-274

Dunkl I, Di Gulio A, Kuhlemann J (2001) Combination of single-grain fission-track chronology and morphological analysis of detrital zircon crystals in provenance studies - sources of the Macigno Formation (Apennines, Italy). J Sed Research 71:516-525

Foster DA, Kohn BP, Gleadow, AJW (1996) Sphene and zircon fission track closure temperatures revisited: empirical calibrations from ${ }^{40} \mathrm{Ar} /{ }^{39} \mathrm{Ar}$ diffusion studies on K-feldspar and biotite. International Workshop on Fission Track Dating, Abstracts, Gent 37

Galbraith RF, Green PF (1990) Estimating the component ages in a finite mixture. Nuclear Tracks and Radiation Measurements 17:197-206

Garver JI (2003) Etching age standards for fission track analysis. Radiation Measurements 37:47-54

Garver JI, Brandon MT (1994a) Fission-track ages of detrital zircon from Cretaceous strata, southern British Columbia: Implications for the Baja BC hypothesis. Tectonics 13:401-420

Garver JI, Brandon MT (1994b) Erosional denudation of the British Columbia Coast Ranges as determined from fission-track ages of detrital zircon from the Tofino Basin, Olympic Peninsula, Washington: GSA Bull 106:1398-1412 
Garver, JI, and Bartholomew, A (2001) Partial Resetting of fission tracks in detrital zircon: Dating low Temperature events in the Hudson Valley (NY): GSA Abstracts with Programs 33: 82

Garver JI, Kamp PJJ (2002) Integration of zircon color and zircon fission track zonation patterns in Orogenic belts: Application of the Southern Alps, New Zealand. Tectonophysics 349:203-219

Garver JI, Brandon MT, Roden-Tice MK, Kamp PJJ (1999) Exhumation history of orogenic highlands determined by detrital fission track thermochronology. In Ring U, Brandon MT, Willett SD, Lister GS (eds) Exhumation processes: Normal faulting, ductile flow, and erosion. Geol Soc London Spec Pub 154:283-304

Garver JI, Brandon MT, Bernet M, Brewer I, Soloviev AV, Kamp PJJ, Meyer N (2000a) Practical considerations for using detrital zircon fission track thermochronology for provenance, exhumation studies, and dating sediments. In Noble WP, O'Sullivan PB, Brown RW (eds) The Ninth International Conference of Fission-track Dating and Thermochronology, Geol Soc Australia - Abstracts 58:109-111

Garver JI, Soloviev AV, Bullen ME, Brandon MT (2000b) Towards a more complete record of magmatism and exhumation in continental arcs using detrital fission-track thermochronometry. Phys Chem Earth $25: 565-570$

Garver JI, Riley BCD, Wang, G (2002) Partial resetting of fission tracks in detrital zircon. European Fissiontrack conference, Cadiz, Spain, Geotemas 4:73-75

Garver JI, Reiners PR, Walker LJ, Ramage JR, Perry SE, (2005) Implications for timing of Andean uplift based on thermal resetting of radiation-damaged zircon in the Cordillera Huayhuash, northern Perú. J Geol. v. 113, n. 2, p. 117-138.

Gastil RG, DeLisle M, Morgan J (1967) Some effects of progressive metamorphism on zircons. GSA Bull 78:879-906

Harrison TM, Armstrong RL, Naeser CW, Harakal JE (1979) Geochronology and thermal history of the Coast Plutonic Complex, near Prince Rupert, British Columbia. Can J Earth Sci 16:400-410

Hasebe N, Tagami T (2001) Exhumation of an accretionary prism -results from fission track thermochronology of the Shimanto Belt, southwest Japan. Tectonophysics 331:247-267

Hasebe N, Tagami T, Nishimura S (1993) Evolution of the Shimanto accretionary complex: A fission-track thermochronological study. In Underwood MB (ed) Thermal Evolution of the Tertiary Shimanto Belt, Southwest Japan: An example of Ridge-Trench Interaction. GSA Spec Pub 273:121-136 
Haughton PDW, Todd SP, Morton AC (1991) Sedimentary provenance studies. In Morton AC, Todd SP, Haughton PDW (eds) Developments in sedimentary provenance studies Geol Soc London Spec Pub 57:1-11

Heller PL, Tabor RW, O'Neil, JR, Pevear DR, Shafiquillah M, Winslow NS (1992) Isotopic provenance of Paleogene sandstones from the accretionary core of the Olympic Mountains, Washington: GSA Bull 104:140-153

Hinderer M (2001) Late Quaternary denudation of the Alps, valley and lake fillings and modern river loads. Geodinamica Acta 14: 231-263

Hourigan JK, Brandon MT, Garver JI, Soloviev AV (2001) A Comparison of the detrital zircon grain-age distributions from the Ukelayat Group and the Kamchatskiy Complex: Implications for the origin of the Sredinniy Range, Kamchatka. Seventh Zoneshain International Conference on plate tectonics, Moscow, Russia 504

Hurford AJ (1986) Cooling and uplift patterns in the Lepontine Alps, South Central Switzerland and an age of vertical movement on the Insubric fault line. Contrib Mineral Petrol 92:413-427

Hurford AJ, Carter A (1991) The role of fission track dating in discrimination of provenance. In Morton AC, Todd SP, Haughton PDW (eds) Developments in sedimentary provenance studies Geol Soc London Spec Pub 57:67-78

Kowallis BJ, Heaton JS, Bringhurst K (1986) Fission-track dating of volcanically derived sedimentary rocks. Geology 14:19-22.

Kuhlemann J (2000) Post-collisional sediment budget of circum-Alpine basins (Central Europe). Memorie degli Istituti di Geologia e Mineralogia dell' Universita di Padova 52:1-91

Kuhlemann J, Frisch W, Székely B, Dunk1 I, Kazmér M (2002) Post-collisional sedimenty budget histroy of the Alps: tectonic versus climatic control. Int J Earth Sci 91:818-837

Liu TK, Hseih S, Chen Y-G, Chen W-S (2001) Thermo-kinematic evolution of the Taiwan obliquecollision mountain belt as revealed by zircon fission track dating. EPSL 186:45-56

Lonergan L, Johnson C (1998) Reconstructing orogenic exhumation histories using synorogenic zircons and apatites: An example from the Betic Cordillera, SE Spain. Basin Research 10:353-364

Mange MA, Maurer HFW (1992) Heavy Minerals in Colour. Chapman and Hall, London 
Meyer NR, Garver JI (2000) Zircon fission-track fingerprint of major tributaries to the Mississippi River. GSA Abstracts with Program 32:59

Morton AC (1984) Stability of detrital heavy minerals in Tertiary sandstones of the North Sea Basin. Clay Minerals 19:287-308

Naeser ND, Zeitler PK, Naeser, CW, Cerveny PF (1987) Provenance studies by fission track dating of zircon - Etching and counting procedures. Nuclear Tracks and Radiation Measurements 13:121-126

Poldervaart A (1955) Zircon in rocks 1, Sedimentary rocks. Am J Sci 235:433-461

Poldervaart A (1956) Zircon in rocks 2, Igneous rocks. Am J Sci 234:521-554

Pupin, JP (1980) Zircon and Granite petrology. Contrib Mineral Petrol 73:207-220

Rahl JM, Reiners PW, Campbell IH, Nicolescu S, Allen CM (2003) Combined single-grain (U-Th)/He and $\mathrm{U} / \mathrm{Pb}$ dating of detrital zircons from the Navajo Sandstone, Utah. Geology 31:761-764

Rahn MK, Brandon MT, Batt GE, Garver JI (2004) A zero-damage model for fission-track annealing in zircon. Am Mineral 89:473-484

Reiners PW (2005) Zircon (U-Th)/He Dating. In Reiners PW, Ehlers T (eds) Low-Temperature thermochronology, Rev Mineral Geochem Series XX:XX-XX

Reiners PW, Campbell IS, Nicolescu S, Allen CA, Hourigan JK, Garver JI, Mattinson, JM, Cowan DS $(200 \mathrm{X})(\mathrm{U}-\mathrm{Th}) /(\mathrm{He}-\mathrm{Pb})$ “double-dating” of detrital zircons. Am J Sci XX:XX-XX in review

Ruiz GMH, Seward D, Winkler W (2004) Detrital thermochronology - a new perspective on hinterland tectonics, an example from the Andean Amazon Basin, Ecuador. Basin Research 16:413-430

Sambridge MS, Compston W (1994) Mixture modeling of multi-component data sets with application to ion probe zircon ages. ESPL 128:373-390

Schlunegger F, Melzer J, Tucker GE (2001) Climate, exposed source-rock lithologies, crustal uplift and surface erosion: a theoretical analysis calibrated with data from the Alps/North Alpine Foreland Basin system. Int J Earth Sci 90:484-499

Shapiro MN, Soloviev AV, Garver JI, Brandon MT (2001) Sources of zircons from Cretaceous and Lower Paleogene terrigenous sequences of the southern Koryak upland and western Kamchatka. Lithology and Mineral Resources 36:322-336 
Sircombe KN, Hazelton ML (2004) Comparison of detrital zircon age distributions by kernel functional estimation. Sedimentary Geology 171:91-111

Soloviev AV, Garver JI, Shapiro, MN (2001) Fission-track dating of detrital zircon from sandstone of the Lesnaya Group, northern Kamchatka. Stratigraphy and Geological Correlation 9:293-303

Soloviev AV, Shapiro MN, Garver JI, Shcherbinina EA, Kravchenko-Berezhnoy IR (2002) New age data from the Lesnaya Group: A key to understanding the timing of arc-continent collision, Kamchatka, Russia. The Island Arc 11:79-90

Spiegel C, Kuhlemann J, Dunkl I, Frisch W, von Eynatten H, Balogh K (2000) The erosion history of the Central Alps: Evidence from zircon fission-track data of the foreland basin sediments. Terra Nova $12: 163-170$

Spiegel C, Siebel W, Kuhlemann J, Frisch W (2004) Towards a comprehensive provenance analysis: a multi-method approach and its implications for the evolution of the Central Alps. In Bernet M, Spiegel C (eds) Detrital Thermochronology - Provenance Analysis, Exhumation, and Landscape Evolution of Mountain Belts. GSA Spec Pub 378:37-50

Stewart RJ, Brandon MT (2004) Detrital zircon fission-track ages for the "Hoh Formation": Implications for late Cenozoic evolution of the Cascadia subduction wedge. GSA Bull 116:60-75

Tagami T (2005) Zircon fission-track dating. In Reiners PW, Ehlers T (eds) Low-Temperature Thermochronometry. Rev Mineral Geochem Series XX:XX-XX

Vermeesch P (2004) How many grains are needed for a provenance study? EPSL 224:441-451

Wagner G, Van den Haute P (1992) Fission-track dating: Solid Earth Sciences Library, Kluwer Academic Publishers, Amsterdam

Willett SD, Fisher D, Fuller C, En-Chao Y, Chia-Yu L (2003) Erosion rates and orogenic-wedge kinematics in Taiwan inferred from fission-track thermochronometry. Geology 31:945-948

Zaun PE, Wagner GA (1985) Fission-track stability in zircons under geological conditions. Nuclear Tracks 10:303-307

Zeitler PK, Johnson MN, Briggs ND, Naeser CW (1986) Uplift history of the NW Himalaya as recorded by fission-track ages of detrital Siwalik zircons. In Jiqing H (ed) Proceedings of the Symposium on Mesozoic and Cenozoic Geology. Geological Publishing House, Beijing, p 481-494 
Table 1. Relative zircon concentration by source lithology

\begin{tabular}{|c|c|c|c|}
\hline Source lithology & High concentration & $\begin{array}{l}\text { Intermediate } \\
\text { concentration }\end{array}$ & $\begin{array}{c}\text { Low to no } \\
\text { concentration }\end{array}$ \\
\hline Igneous rocks & $\begin{array}{c}\text { granite, granodiorite, } \\
\text { tonalite }\end{array}$ & rhyolite, ignimbrite & $\begin{array}{l}\text { gabbro, ultramafic } \\
\text { rocks, basalt }\end{array}$ \\
\hline Metamorphic rocks & orthogneiss & $\begin{array}{l}\text { paragneiss, meta- } \\
\text { rhyolite, meta- } \\
\text { sandstone, phyllites }\end{array}$ & marble, eclogite, schist \\
\hline Sedimentary rocks & arkose & $\begin{array}{l}\text { conglomerates, quartz } \\
\text { arenite, litharenite, } \\
\text { siltstone }\end{array}$ & $\begin{array}{l}\text { claystone, dolomite } \\
\text { carbonate rocks }\end{array}$ \\
\hline
\end{tabular}

Note: Relative zircon concentrations are based on Poldervaart $(1955,1956)$ and Deer et al. (1992) 
Table 2. Sandstone sample size for DZFT analysis

\begin{tabular}{lc}
\hline \multicolumn{1}{c}{ Lithology } & weight \\
\hline Arkose & $2-4 \mathrm{~kg}$ \\
Quartzo-feldspathic sandstone & $\sim 4 \mathrm{~kg}$ \\
Quartz-bearing volcaniclastic sandstone & $4-7 \mathrm{~kg}$ \\
Lithic sandstone & $4-7 \mathrm{~kg}$ \\
Silicic volcaniclastic sandstone & $2-4 \mathrm{~kg}$ \\
\hline
\end{tabular}


Table 3. Summary of mineral separation steps Separation step

1) Crush and pulverize the rock

2) Separate the sample using a shaking table (e.g. Rogers or Gemeni table).

3) (optional) Sieving with $0.25-0.088 \mathrm{~mm}$ sieves. Process only the $0.25-0.088 \mathrm{~mm}$ fraction. Store the $>0.25$ and $<0.088$ $\mathrm{mm}$ fractions.

4) Separate heavy minerals from light-mineral contaminates by passing the sample through heavy liquids (i.e. Sodium polytungstate or Tetrabromoethane).

5) Pass the heavy fraction through the Frantz magnetic separator stepwise at $0.1-1.5 \mathrm{amp}$. (Possible to loose Fe-rich zircon during this separation step).

6) Process the nonmagnetic fraction in heavy liquid (i.e. Methylene iodide). 


\section{Figure captions}

Figure 1. Suite of detrital zircon showing the whole spectrum of zircon shapes and colors that encountered in detrital samples. This particular samples is a suite of zircon from a single sandstone sample of the Eocene Ukelayet Flysch, Northern Kamchatka, Russia. Several end members are worth noting (see text for discussion): 1) Very wellrounded grains are likely to be polycyclic; 2) Colorless with little damage and/or low REE; 3) Colorless and euhedral; 4) Grains of the red series; 5) Grains of the yellow series.

Figure 2. Closure-temperature as a function of cooling rate, given for apatite, zircon and titanite (U-Th)/He and apatite and zircon FT thermochronometers. All curves are calculated after Dodson (1973). Field-based estimates of the zircon fission-track closure temperature are shown from Harrison et al. (1979), Zaun and Wagner (1985), Hurford (1986), Brandon and Vance (1992), Foster et al. (1996), and Bernet (2002).

Figure 3. Plot showing the general range of expected grain-age distributions and uranium concentrations in typical detrital zircon suites. Note that the upper right field has no data points because these zircons have track densities that are too dense to count using standard methodologies. The lower left field, largely empty, corresponds to grains that are generally underetched in most analyses, but long etch times (c. 50-150 hr) could have captured them in these cases. Data Sources: Crimea (Soloviev, unpublished); Kamchatka (Garver et al. 2000); Appalachian rivers (Meyer and Garver, 2000); Southern Alps (Garver and Kamp 2002); Indus River (Cerveny et al., 1988); Mississippi River (Meyer and Garver, 2000), Himalaya rivers (Brewer, unpublished); European Alps (Bernet et al. 2004b).

Figure 4. Uranium concentration and FT age correlation of detrital zircon, shown here in relation to etch time duration. Note that long tech times tend to reveal countable tracks in grains with higher $U$ concentrations and younger cooling ages. The reason for this is that grains with younger cooling ages have less radiation damage accumulated and the grains are more pristine, reducing the etching efficiency. Grains with older cooling ages and higher radiation damage etch more easily and therefore have shorter etch times. Etching 
was done in a $\mathrm{NaOH}: \mathrm{KOH}$ eutectic in Teflon dishes at $228^{\circ} \mathrm{C}$ in a laboratory oven. All data are from modern river sediment (Bernet et al. 2004a, b).

Figure 5. Shown are the various possibilities to present detrital zircon FTGA distributions and best-fit peaks in probability density and radial plots. The data shown here are from the Ticino River in Italy (Bernet et al. 2004b). A) Histogram and curve of the observed grain-age distribution. B) Histogram and curves of binomial best-fit peaks. C) Curve of observed grain-age distribution and curves of binomial best-fit peaks. D) Radial plot with best-fit peaks. Peak fitting after Galbraith and Green (1990) and (Brandon 1996) using BINOMFIT from Brandon.

Figure 6. The lag-time of a sample is the time required for the sample to cool, get exhumed to the surface, and then get deposited in a nearby basin. As a rock is exhumed to the surface, the rock cools below the closure temperatures of the different thermochronometers (here only ZFT is shown): when this happens, various isotopic clocks start. Eventually the rock reaches the surface where it is subject to erosion. Apatite, zircon, and mica grains are released into sediment and transported by glaciers and rivers into the adjacent basins, where they are deposited. The time for erosion and sediment transport is generally regarded as geologically instantaneous (Heller et al. 1992; Bernet et al. 2004a), but this is not always the case. Lag time integrates the time between closure and the time of deposition, and mainly represents the time needed to exhume the rock to the surface.

Figure 7. Relationship of FTGA or peak-age and long-term average exhumation rate (for radiation-damaged zircon), shown here for common geothermal gradients of $20^{\circ} \mathrm{C}, 25^{\circ} \mathrm{C}$ and $30^{\circ} \mathrm{C}$ (after Garver et al. 1999). Advection of isotherms during fast exhumation has been considered in constructing this graph.

Figure 8. Schematic lag-time plots based on FTGA peak ages and depositional ages. A) The up-section lag-time trend can be approximated with the linear relationship $t_{c}=A+B$ $t_{d}$ (Bernet et al. 2001). The slope $B$ of the lag-time line is a function of orogenic evolution and can indicate orogenic construction, steady state, or orogenic decay. B) Overall shortening trend of lag time reflects removal of non- or partially reset cover units 
in the beginning and increase in exhumation rate throughout the record. Peak ages are becoming continuously younger and are therefore moving peaks. C) Constant lag times can be observed if zircons always need the same time to pass through the closer temperature, be exhumed, eroded an deposited throughout part of the stratigraphic section. Peak ages also become continuously younger and are also moving peaks. D) Increase in lag time indicates a decrease in exhumation rates, which means that the mountain belt or parts of it became inactive and are decaying way. If peak ages do not change up-section, then these peaks are regarded as static peaks.

Figure 9. A) In areas with active volcanism ZFT analysis can be used to date ash layers to obtain stratigraphic ages, or by determining P1 in contemporaneous sandstone layers (e.g. Garver et al. 2000b; Soloviev et al. 2001; Stewart and Brandon 2004). B) In orogenic settings without active volcanism, FT ages are related to exhumational cooling and depositional ages must be determined with other means, such as biostratigraphy.

Figure 10. Schematic diagram showing exposure of synorogenic cooling ages in a single vergent mountain belt, similar to the Southern Alps in New Zealand. Older, non-reset cooling ages occur in cover units. The hypothetical probability density plot shows the general distribution of FT age components derived from such a setting.

Figure 11. Schematic profile of the Southern Alps of New Zealand, showing zircon color retention and FT annealing zones. Also shown are zircon FTGA distributions and best-fit peaks of the Rangitata and Hokitika rivers that drain the Southern Alps to the east and west respectively.

Figure 12. ZFT ages from poorly dated and undated sandstones associated with the Olyutorsky collision zone, Kamchataka. The young populations have been used to constrain the depositional age of sandstones in the pre- and post-collisional basins. These studies fundamentally changed interpretations of Kamchatka geology because many of these sandstone units were originally mapped as Cretaceous, and it is clear that they must be at least Eocene in a number of cases (from Garver et al. 2000a; Garver unpublished). 
Figure 13. FT peak ages plotted against depositional age of Indus River and Siwalik Group sediments. Contour lines designate lag time. Both P1 and P2 data indicate that the fastest exhuming areas of the Himalayas in NW Pakistan are in a constructional phase since at least the Miocene. Shortening of lag time up-section implies an increase in exhumation rates (data from Cerveny et al. 1988).

Figure 14. P1 and P2 lag-time trends in sediment derived from the European Alps. Samples were collected in the adjacent foreland and hinterland basins. Samples from Italy, France and Germany are from Bernet et al. (2001) and Bernet (2002). Swiss samples are from Spiegel et al. (2000). Note that most samples show relatively constant $\mathrm{P} 1$ and P2 trends (moving peaks) since the early Miocene. The main source areas are indicated as Penninic core, Austroalpine, and Cretaceous to Jurassic cover units in the Alps.

Figure 15. Probability density plots of unreset, partly reset, and fully reset zircons from Cretaceous quartzites in the Cordillera Huayhuash, Perú (from Garver et al., in press). Note that variable resetting results in a complicated grain-age distribution. Once heated, less retentive grains are fully reset, while more retentive grains are unreset or only party reset. A good example of the resulting mixed populations of grains (unreset and fully reset) is shown in 03-16a. This sample retains old grains that are presumably High Retentive Zircon (HRZ)), some grains that are partly reset (mid Tertiary), and a small component of Low Retentive Zircon (LRZ) that are full reset at about $10 \mathrm{Ma}$. Gray lines represent error envelope. Depositional age is Lower Cretaceous (100-120 Ma).

Figure 16. DZFT plot of zircon fission track age and uranium concentration from two units in the mid-Hudson Valley (NY). These Paleozoic sandstones are inferred to have been heated to temperatures in the range of 180 to $200^{\circ} \mathrm{C}$ during the thermal affects associated with opening of the North Atlantic (Garver and Bartholomew, 2001).Depositional age of these units is Silurian and Ordovician, so any grain with a possible provenance age (and hence unreset) falls in the diagonally ruled field. Subsequent heating (gray shaded zone) apparently fully reset a number of grains that collectively define cooling at c. 185 Ma. Heating occurred in the early Mesozoic (MZ) and was associated with the opening of the North Atlantic. 


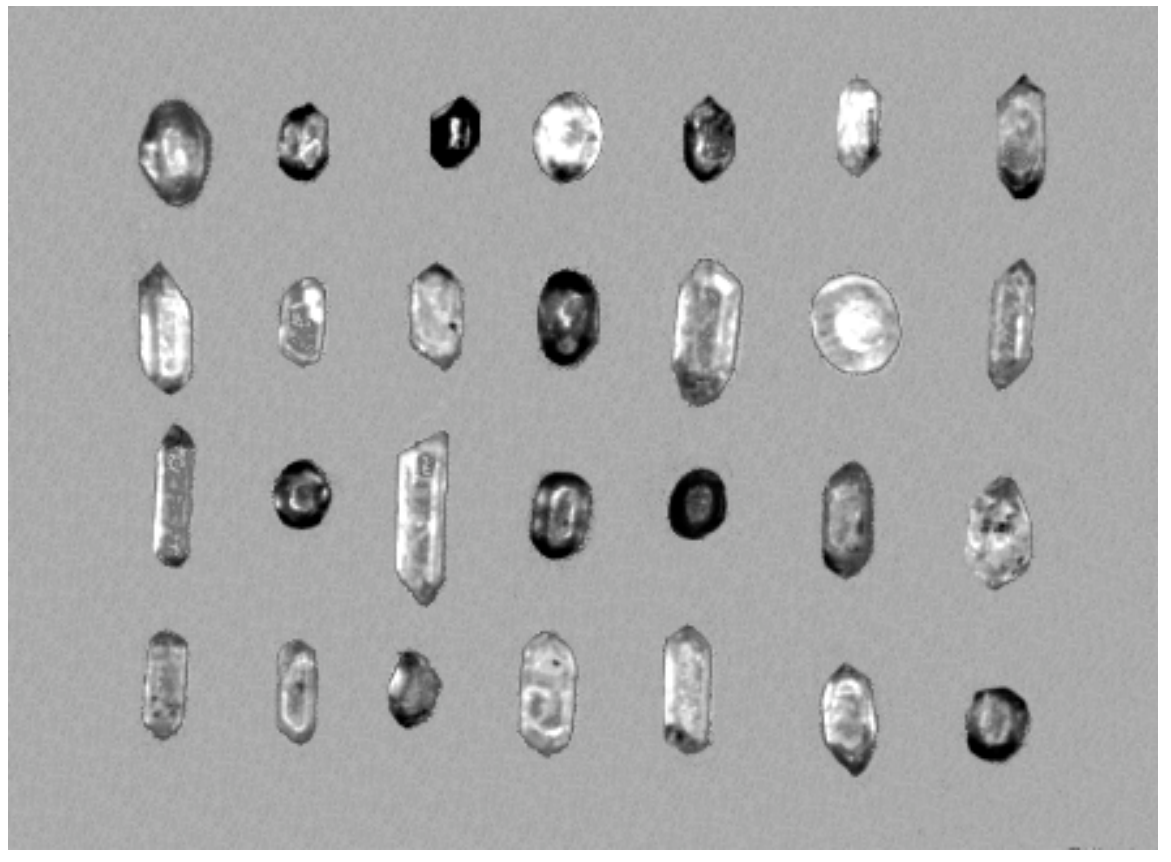




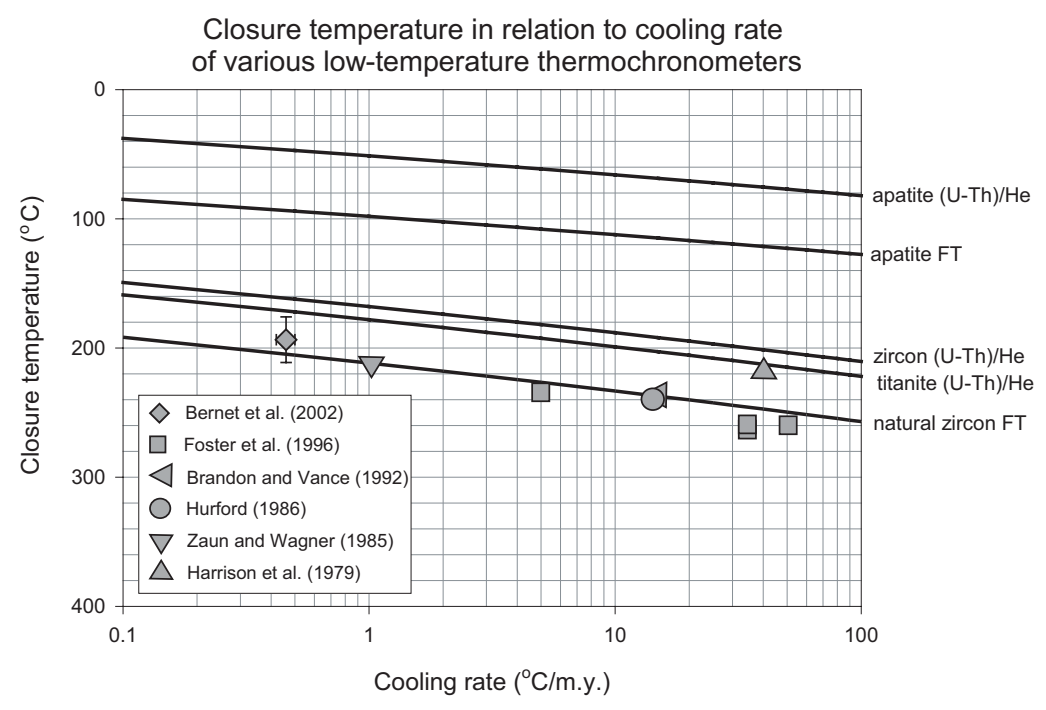

Bernet and Garver Figure 2 


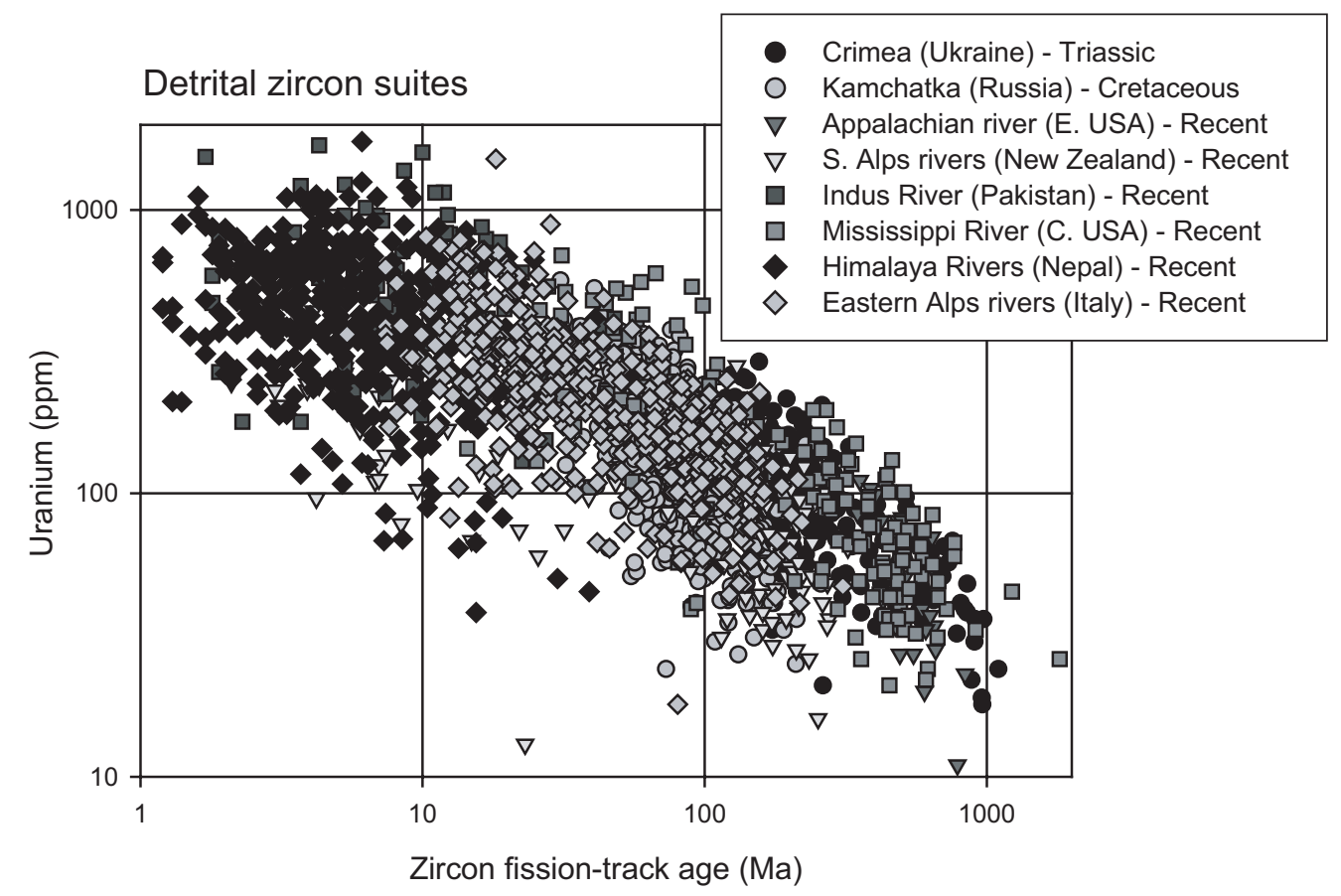

Bernet and Garver Fig. 3 


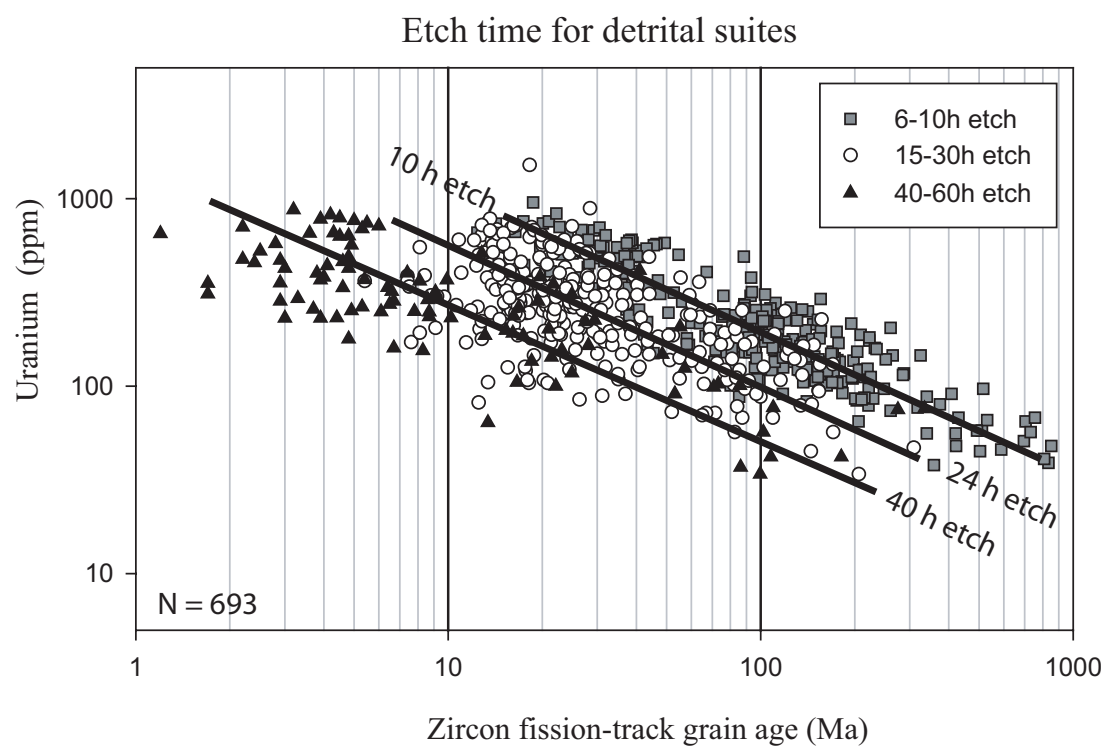

Bernet and Garver Figure 4 

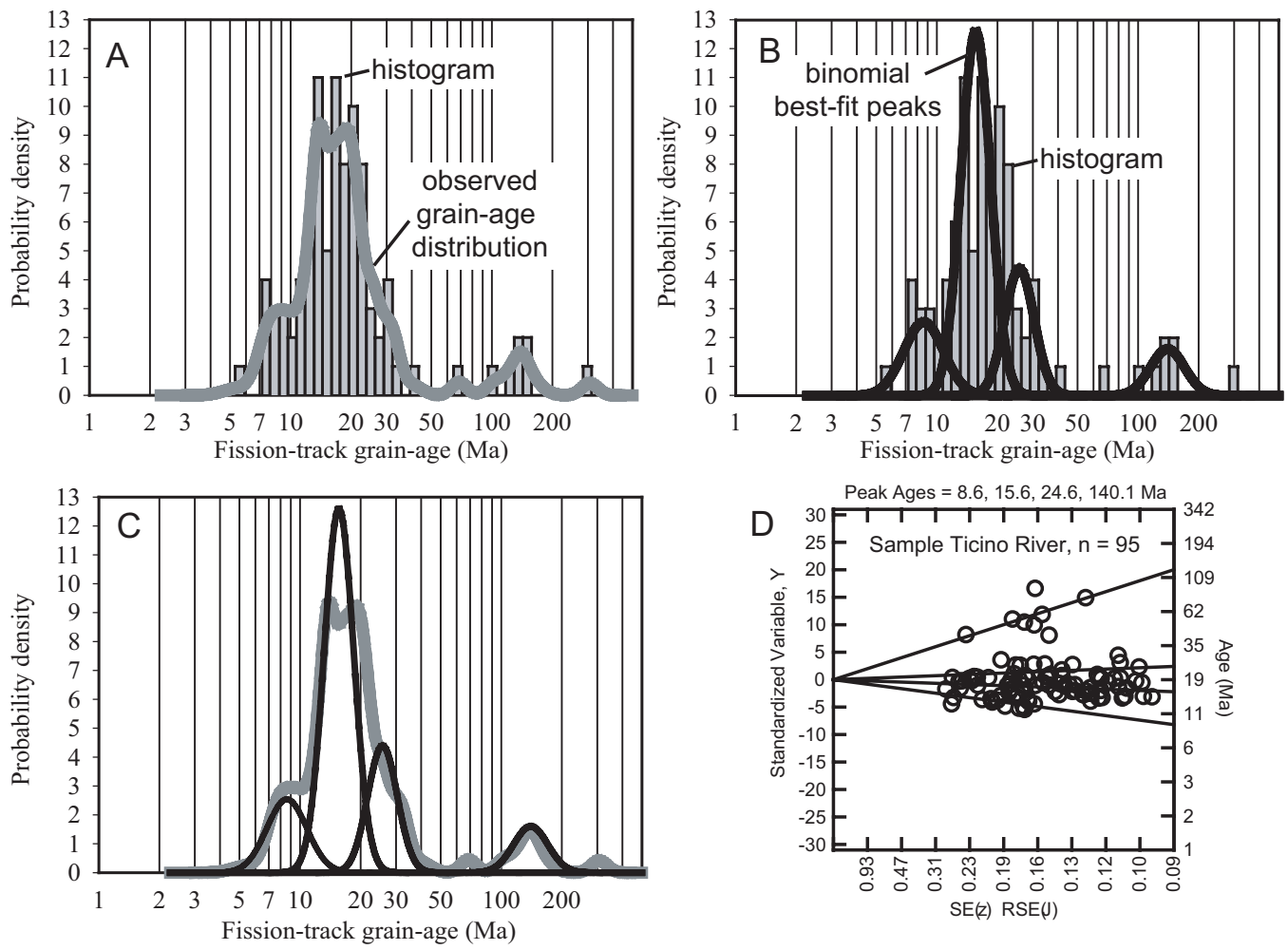

Fig. 5 Bernet and Garver 


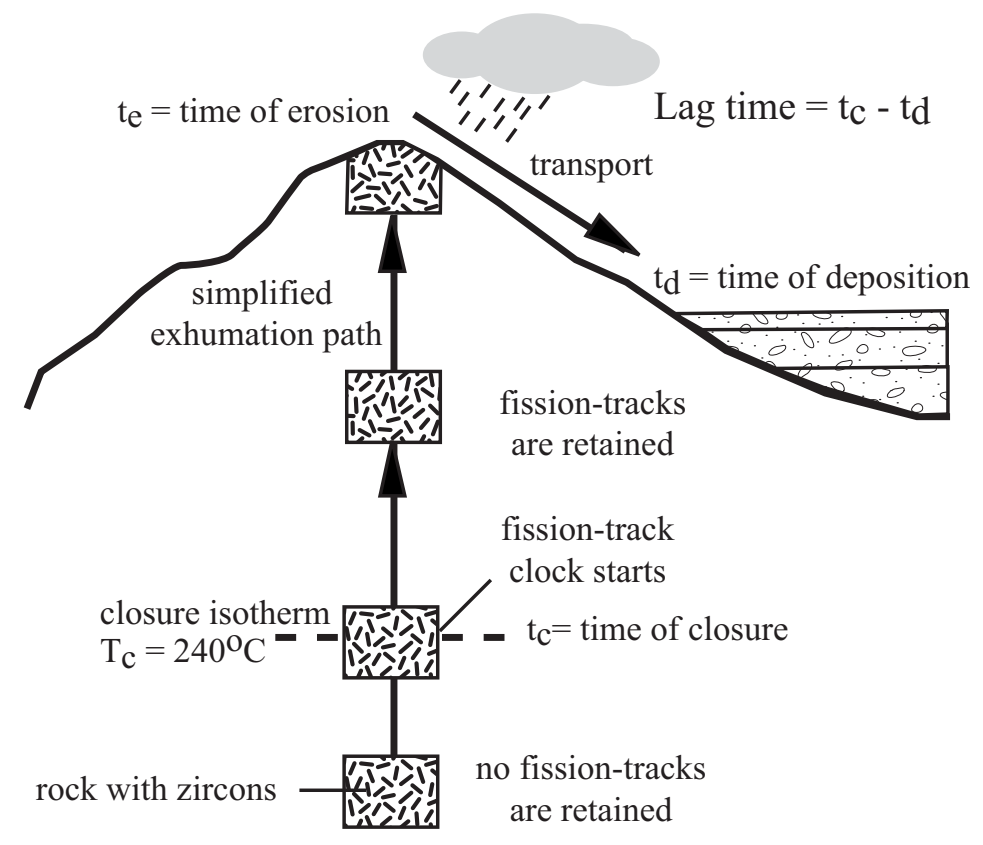

Bernet and Garver Fig. 6 


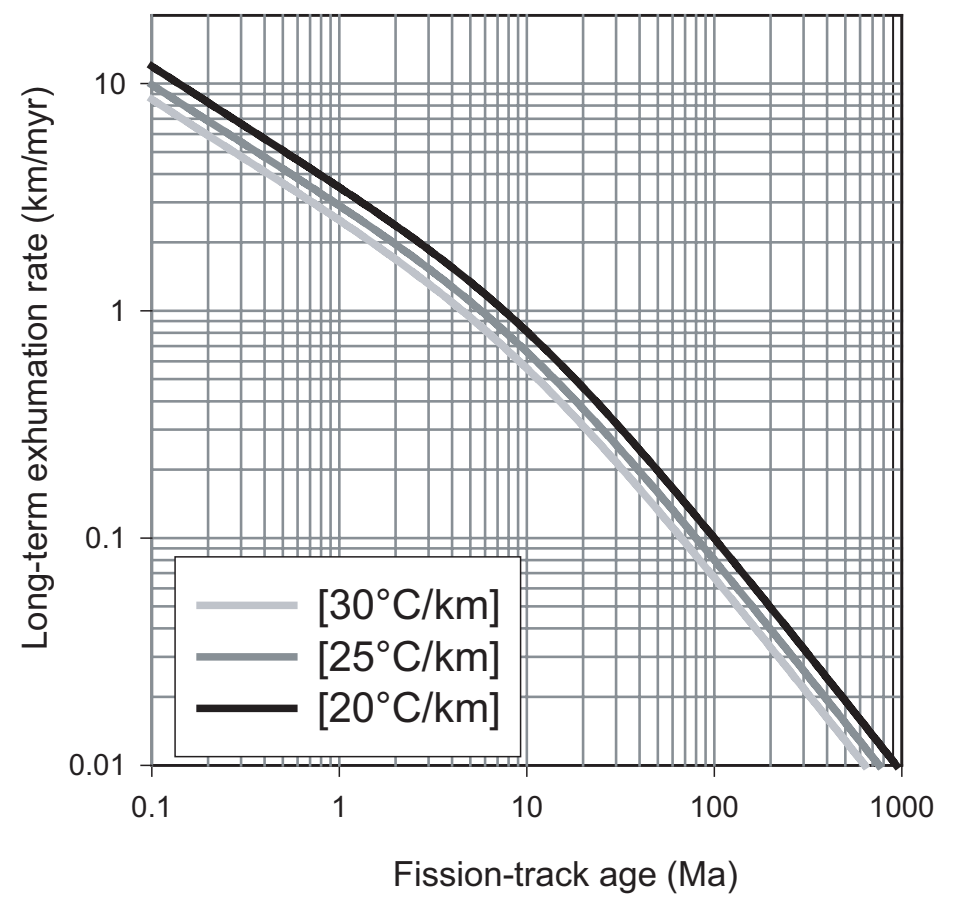

Bernet and Garver Fig. 7 
Simplified lag-time trends

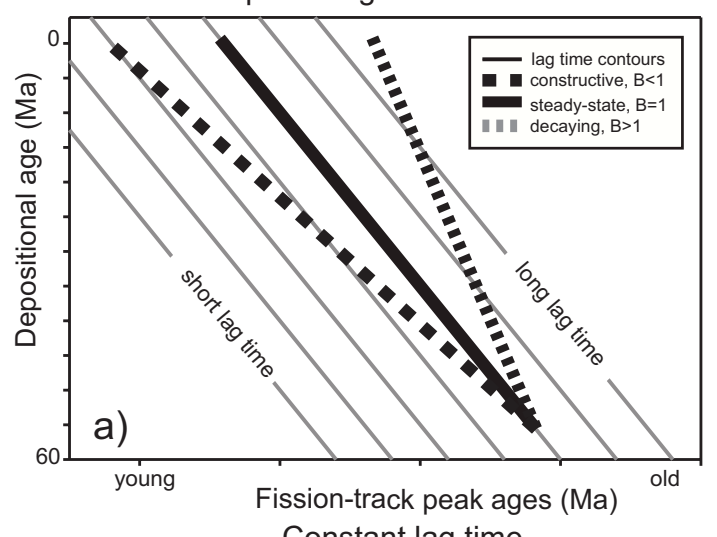
Constant lag time

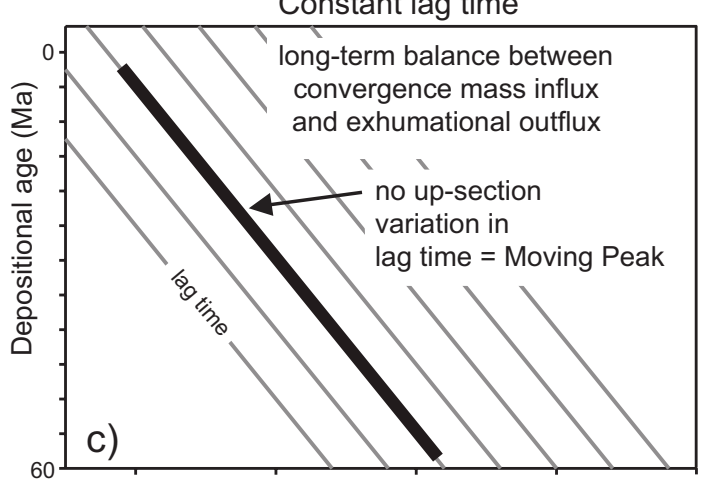

Fission-track peak ages (Ma)
Shortening of lag time

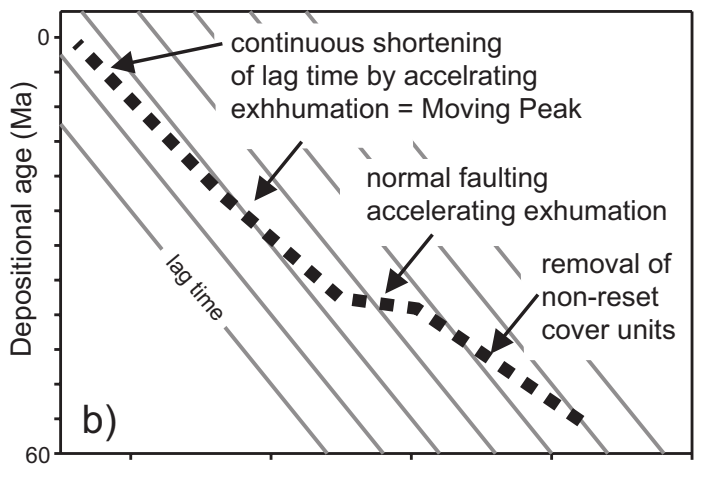

Fission-track peak ages (Ma) Increase of lag time

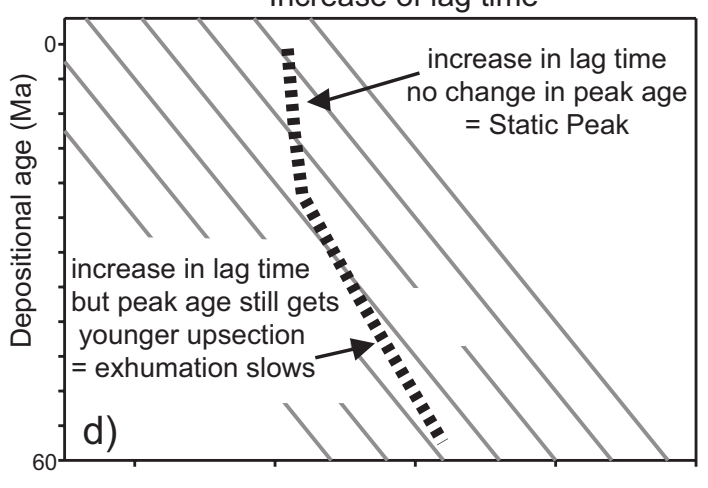

Fission-track peak ages (Ma)

\section{Bernet and Garver Figure 8}



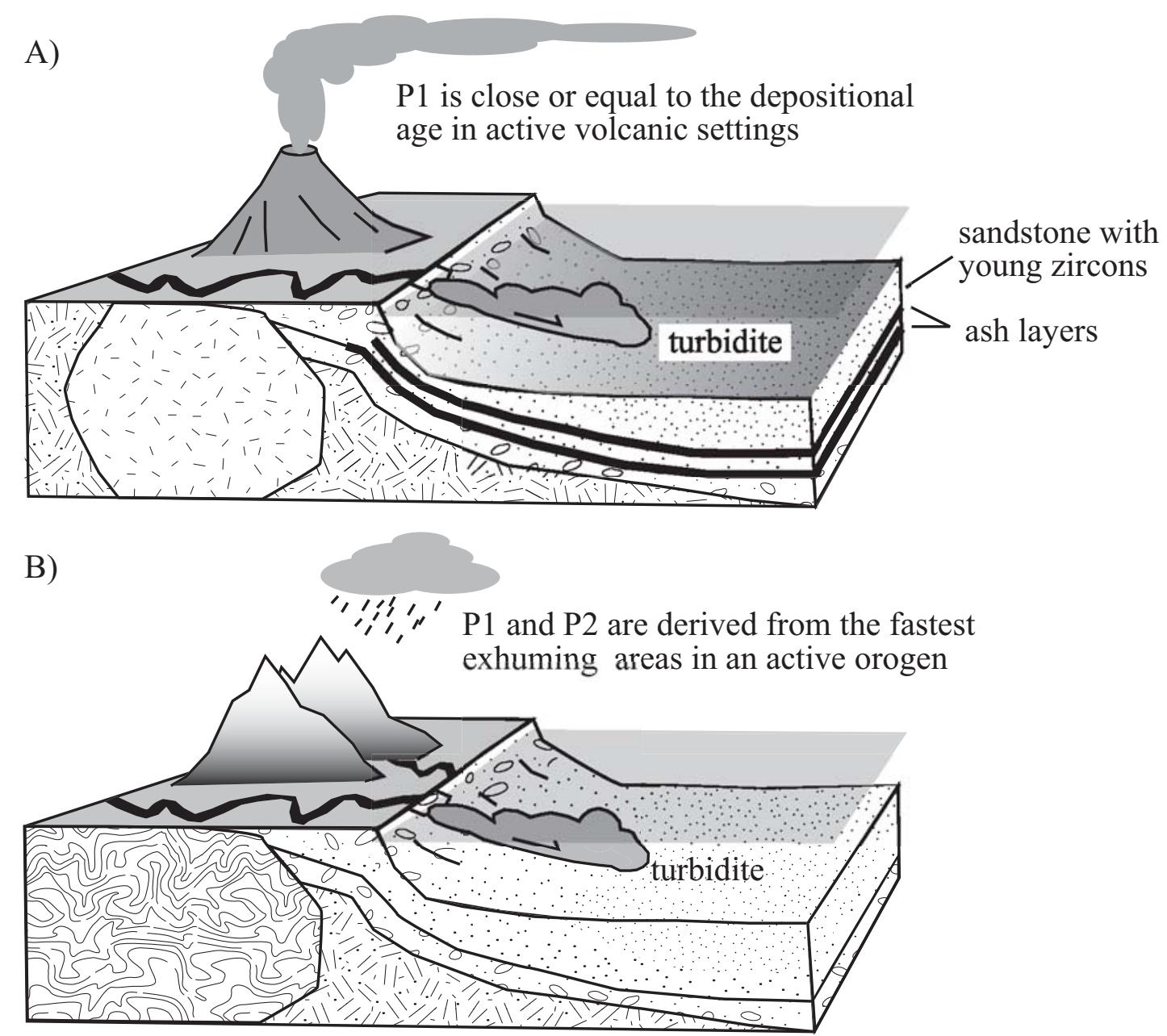

Bernet and Garver Figure 9 


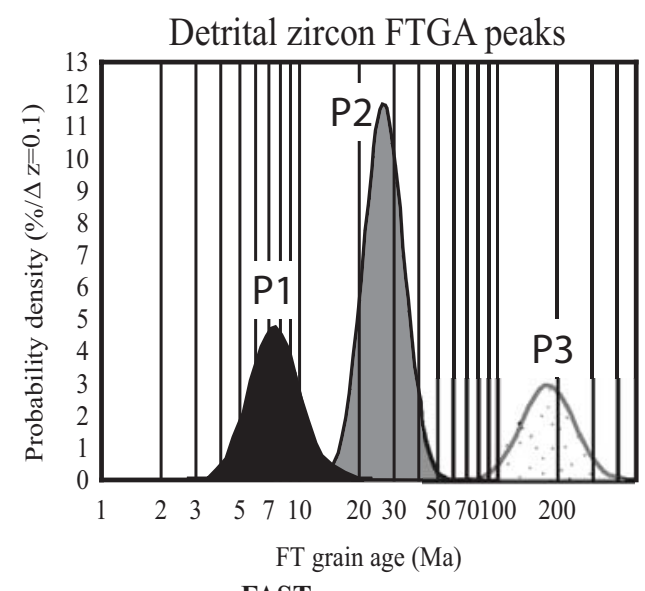

FAST

SLOW

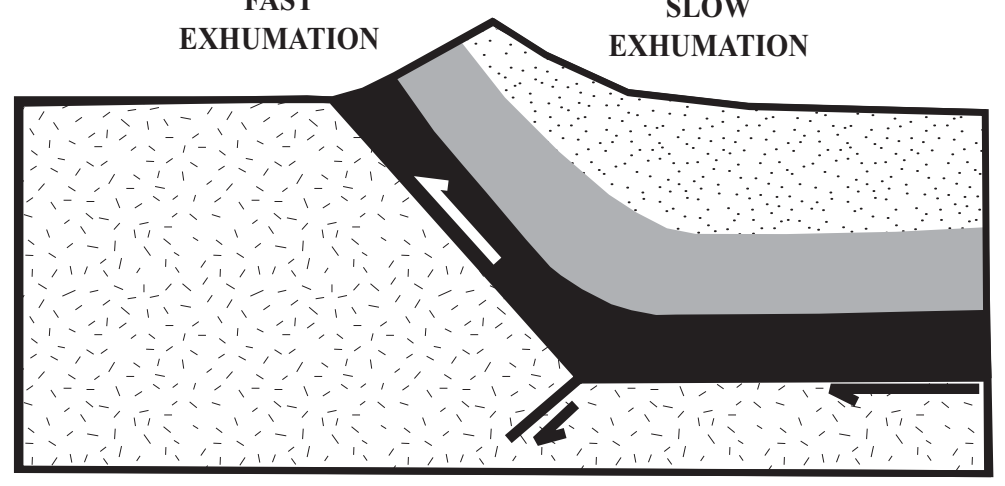

Bernet and Garver Figure 10 
West side - Hokitika River

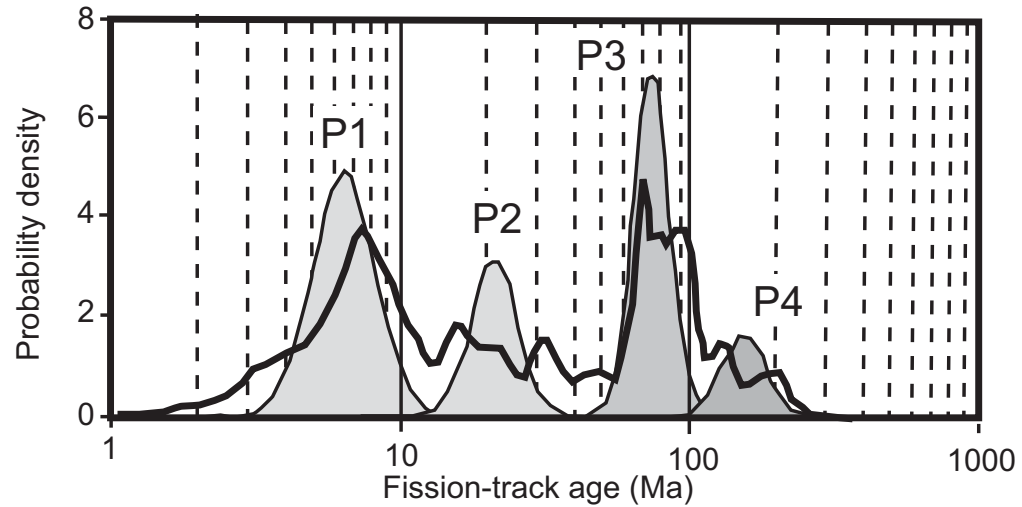

WEST
East side - Rangitata River

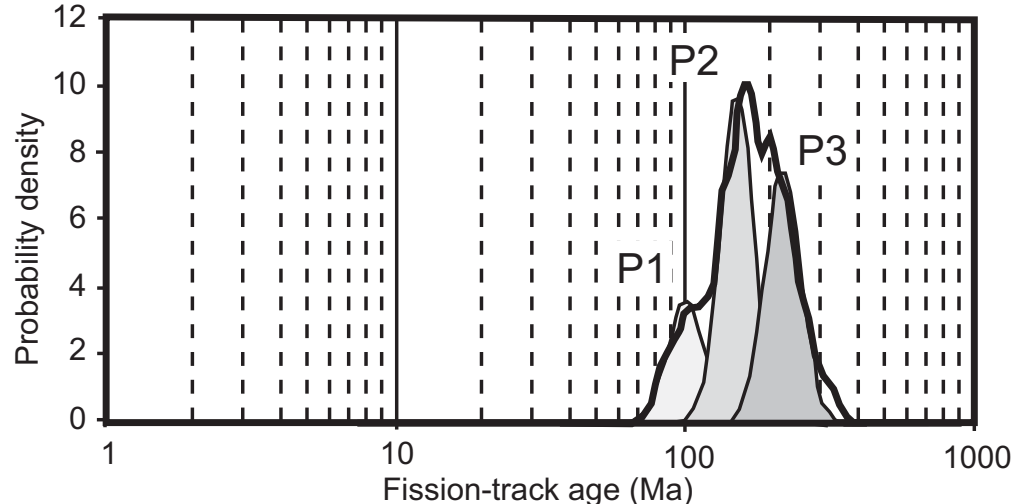

EAST

Drainage divide

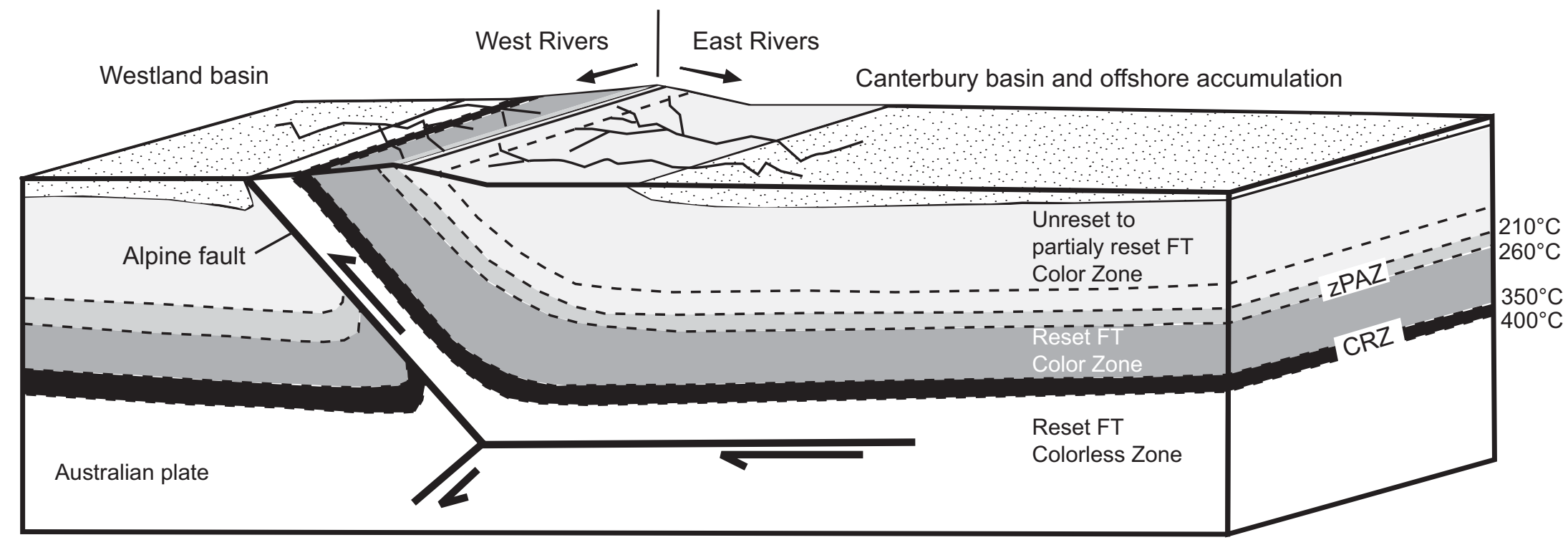


Lesnaya (c. Kam)

Ukelayet (n. Kam.)

Karaginski

\begin{tabular}{|c|c|c|}
\hline \multirow{4}{*}{$\begin{array}{l}0 \\
\\
1 \\
D \\
0 \\
\mathbb{1} \\
Z\end{array}$} & \multirow{4}{*}{ 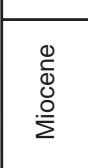 } & \\
\hline & & $\begin{array}{l}\text { Tortonian } \\
\end{array}$ \\
\hline & & Serravallian \\
\hline & & Burdigalian \\
\hline \multirow{7}{*}{ 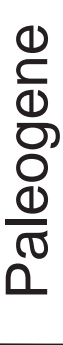 } & \multirow{2}{*}{ 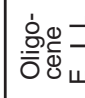 } & Chattian \\
\hline & & Rupelian \\
\hline & \multirow{3}{*}{ 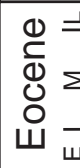 } & $\begin{array}{c}\text { Priabonian } \\
\text { Bartonian }\end{array}$ \\
\hline & & Lutetian \\
\hline & & Ypresian \\
\hline & \lrcorner & Selandian \\
\hline & ш & Danian \\
\hline \multirow{10}{*}{ 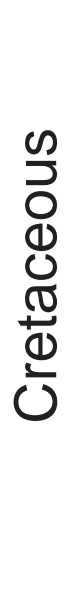 } & \multirow{4}{*}{$\underset{\underbrace{}}{\stackrel{\Phi}{\sigma}}$} & Maastrichtian \\
\hline & & Campanian \\
\hline & & $\begin{array}{c}\text { Santonian } \\
\text { Turonian/Con. }\end{array}$ \\
\hline & & Cenomanian \\
\hline & \multirow{6}{*}{ 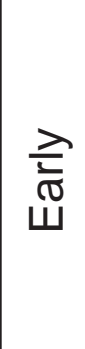 } & Albian \\
\hline & & Aptian \\
\hline & & Barremiann \\
\hline & & Hauterivian \\
\hline & & Valanginian \\
\hline & & Berriasian \\
\hline
\end{tabular}
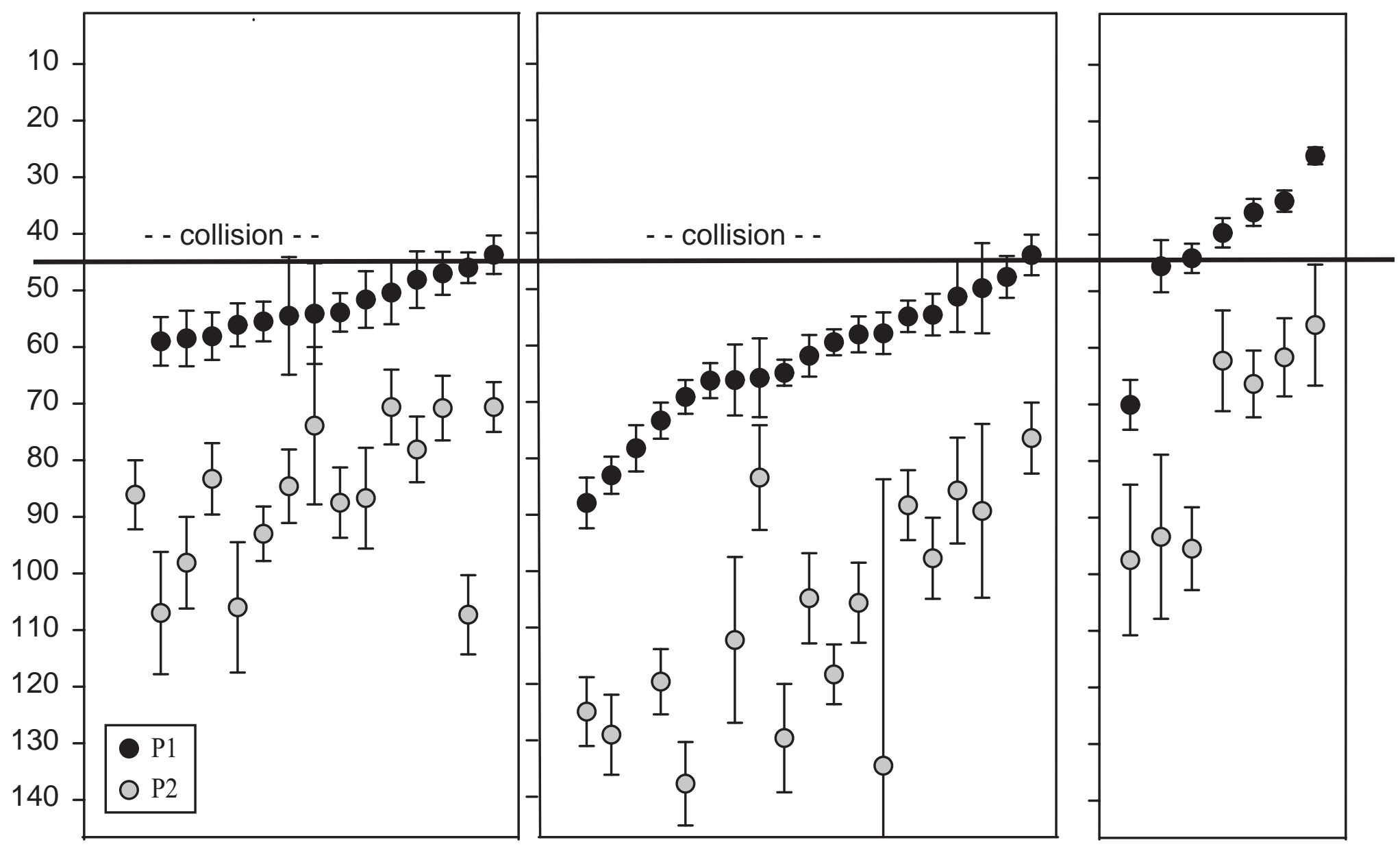


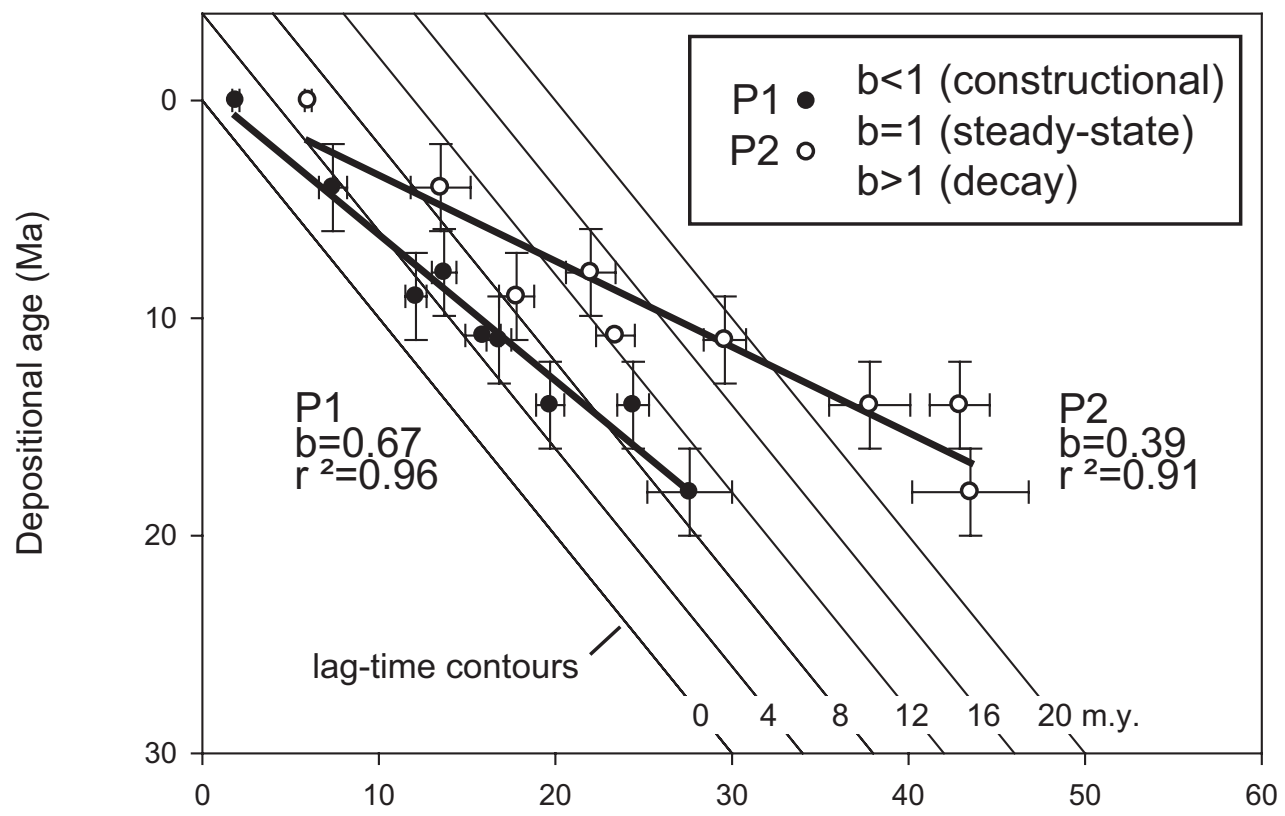

Fission-track peak age (Ma)

Bernet and Garver Figure 13 
Fission-track peak age (Ma)

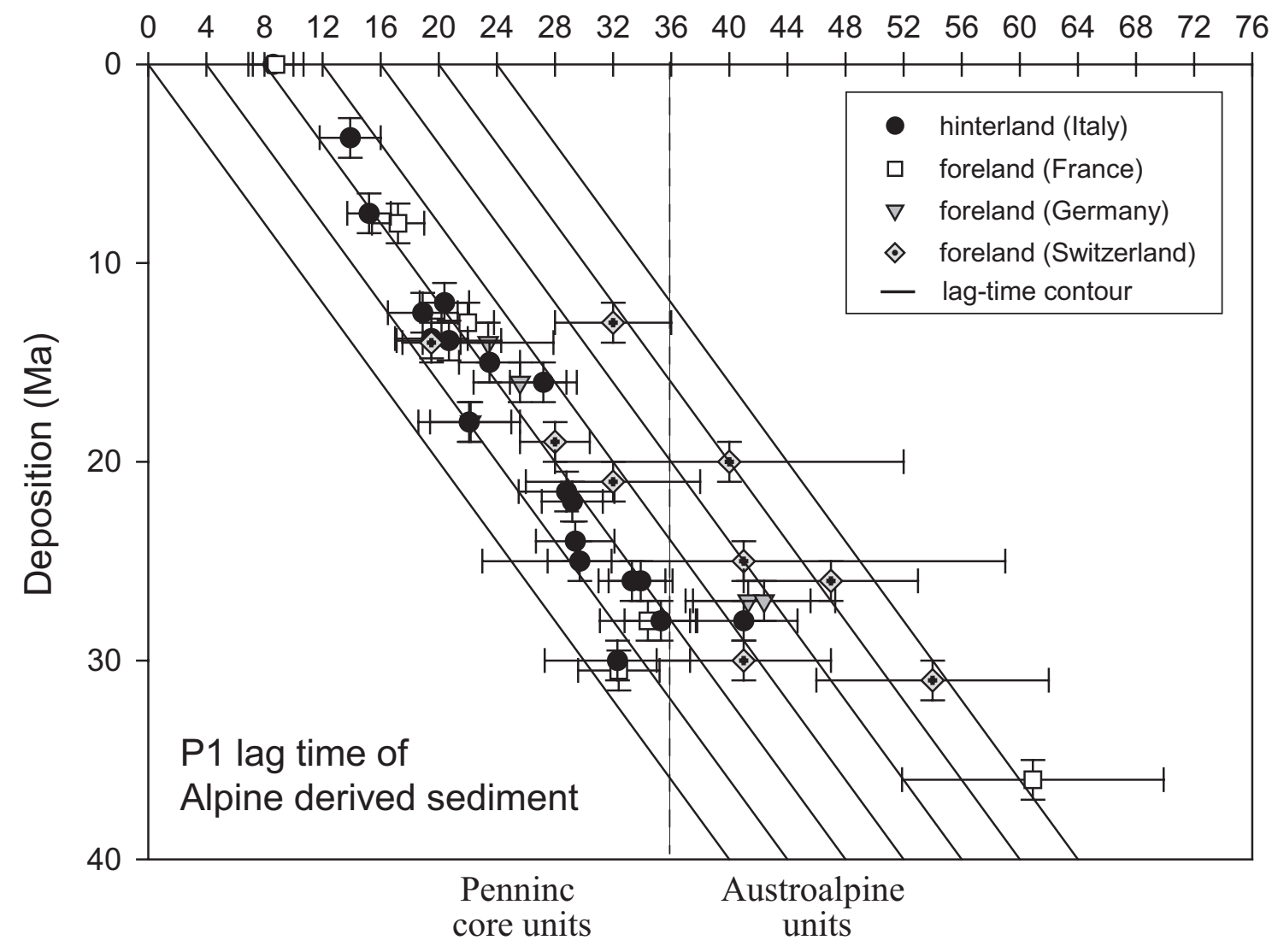

Fission-track peak age (Ma)

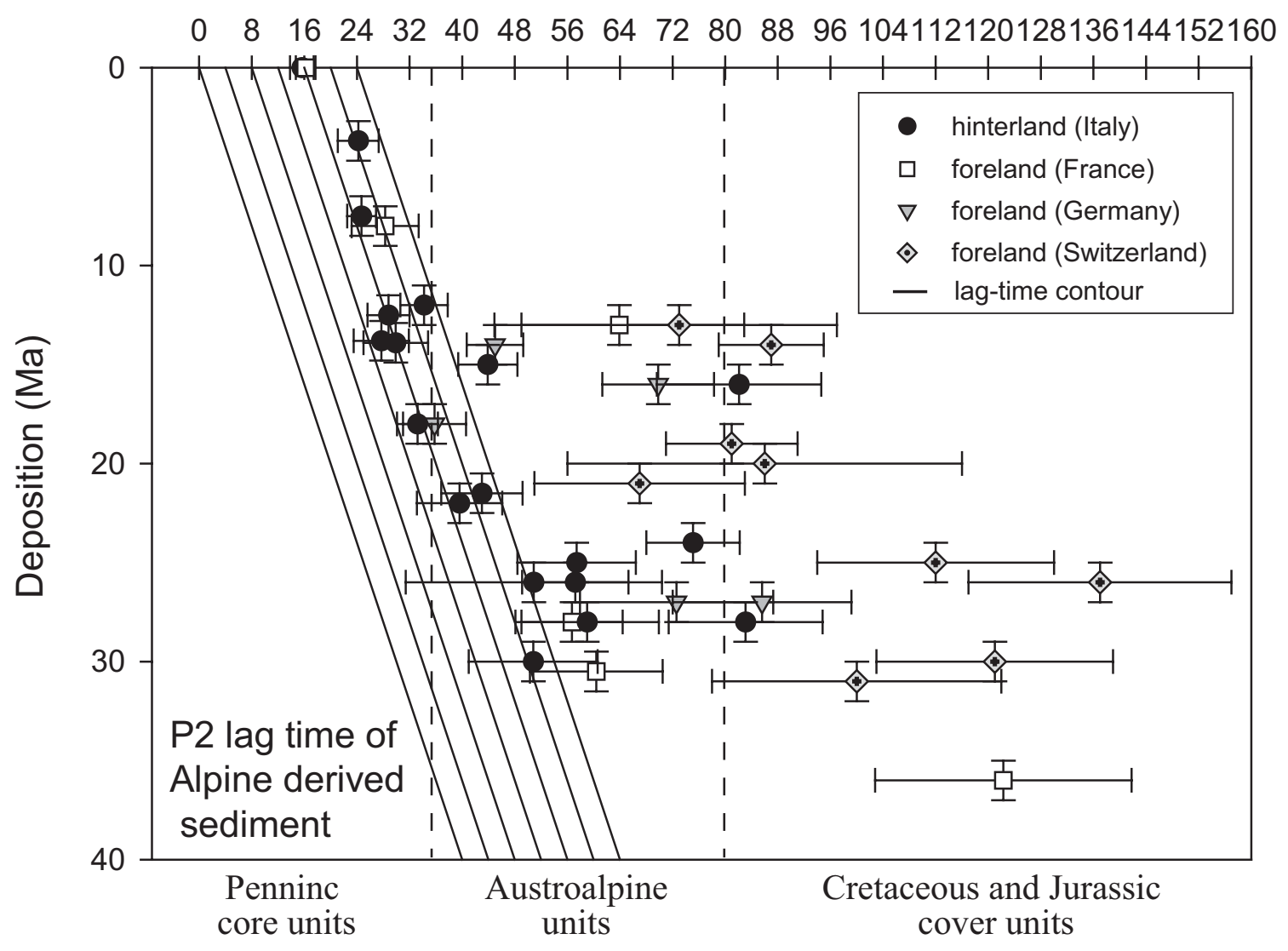

Bernet and Garver Figure 14 


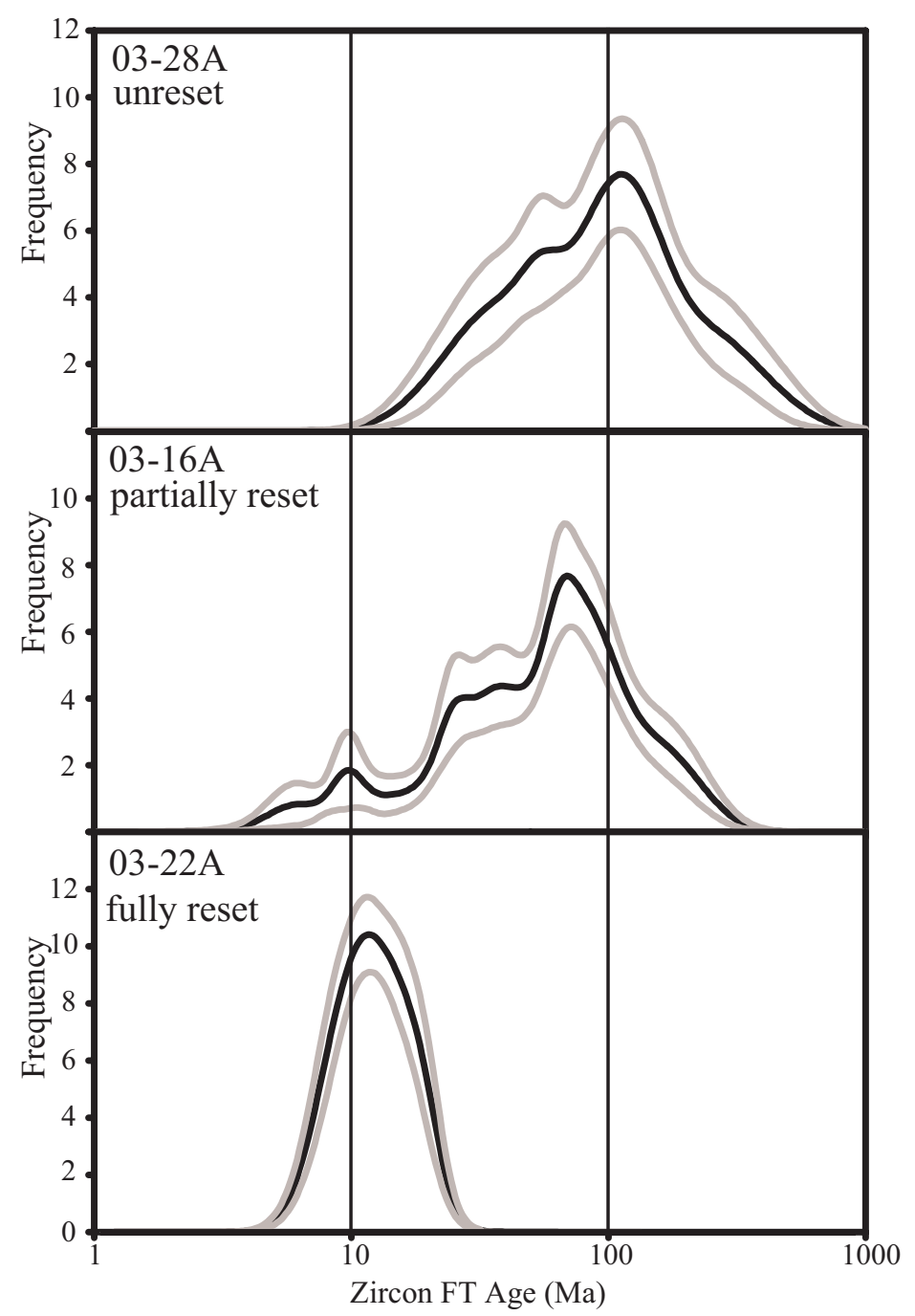

Bernet and Garver Figure 15 


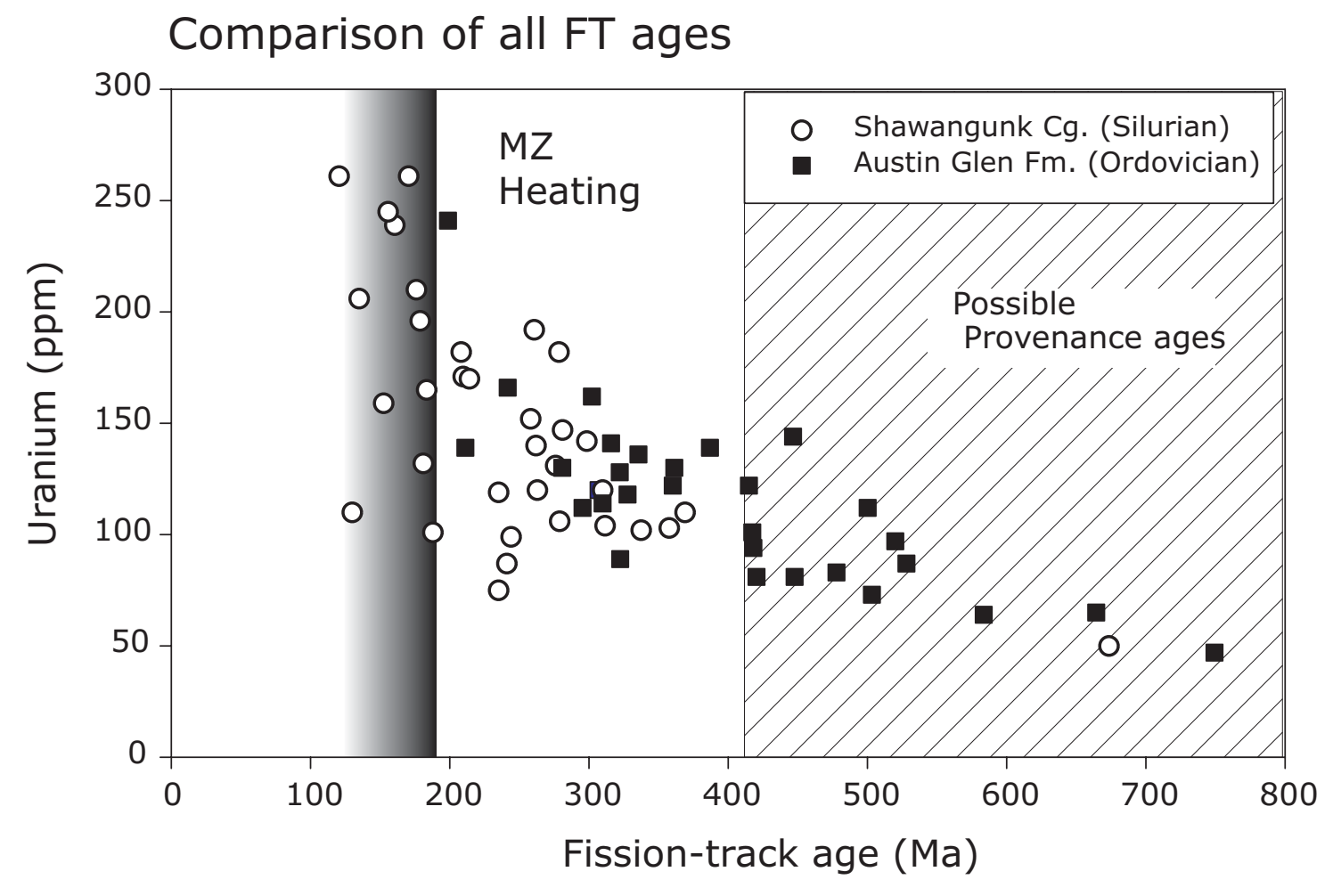

Bernet and Garver Fig. 16 